\title{
Recent Advances in the Immunology and Serological Diagnosis of Echinococcosis
}

\author{
Wenbao Zhang ${ }^{1,2,}$, Jun Li ${ }^{1,2}$, Renyong Lin ${ }^{1}$, \\ Hao Wen ${ }^{1}$ and Donald P. McManus ${ }^{2}$ \\ ${ }^{1}$ State Key Laboratory Breeding Base of Xinjiang Major Diseases Research, \\ Clinical Medicine Institute, \\ First Affiliated Hospital of Xinjiang Medical University, Urumqi, \\ ${ }^{2}$ Molecular Parasitology Laboratory, \\ Australian Centre for International and Tropical Health and Nutrition, \\ The Queensland Institute of Medical Research and \\ The University of Queensland, Brisbane, \\ ${ }^{1}$ China \\ ${ }^{2}$ Australia
}

\section{Introduction}

Echinococcosis is a near-cosmopolitan zoonosis caused by tapeworms (cestodes) belonging to the family Taeniidae and the genus Echinococcus. This parasitic disease is very common but largely neglected. The two major species of medical and public health importance are Echinococcus granulosus $(E g)$ and E. multilocularis $(E m)$, which cause cystic echinococcosis (CE) and alveolar echinococcosis (AE), respectively. Globally, CE is responsible for most of the burden of echinococcosis (Budke, 2006), although AE is re-emerging with increasing frequency in Europe (Deplazes, 2006; Eckert et al., 2000; Romig, 2009; Hegglin et al., 2008).

There are 4 million people infected and more than 100 million at risk of infection including many in the EU countries (Craig and Larrieu, 2006; Craig et al., 2007; McManus et al., 2003). In the endemic regions, human incidence rates can reach more than 50 per 100000 person/year and prevalence as high as $5-10 \%$ may occur, as in parts of Peru, Argentina, east Africa and central Asia (Altintas, 2003; Craig et al., 2007; Moro et al., 1997). In China, there are 60 million people at risk (Ito et al., 2003b) with 550,000 CE patients having visible hydatid cysts by ultrasound (Collaboration projects, 2005; Li et al., 2005) and > 100 million animals infected(Chi et al., 1989).

\section{Life-cycle and Echinococcosis}

The complex life cycle of Echinococcus involves two hosts (Fig 1); a definitive host and an intermediate host. Definitive hosts are carnivores such as dogs, wolves and foxes. Sexual maturity of adult E. granulosus occurs in the host small intestine within 4 to 5 weeks of

${ }^{*}$ Corresponding Author 
ingesting offal containing viable protoscoleces. Gravid proglottids or released eggs are shed in the feces.

Echinococcus granulosus

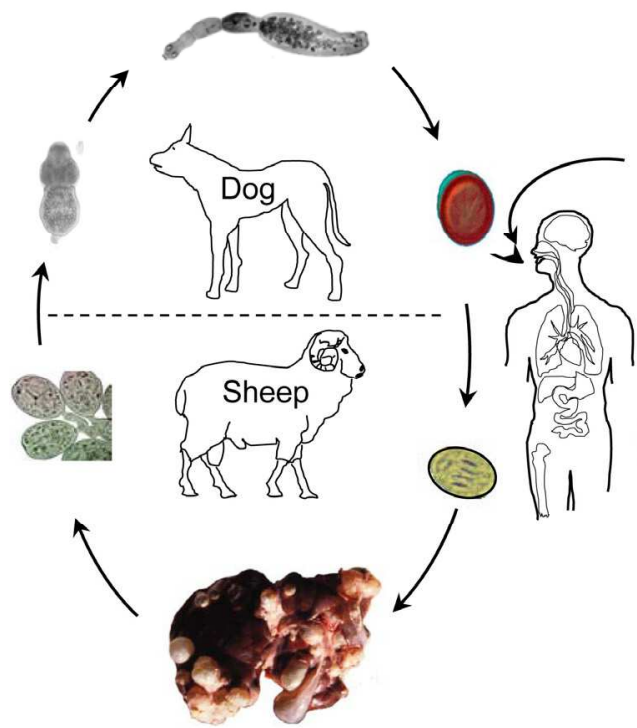

Echinococcus multilocularis

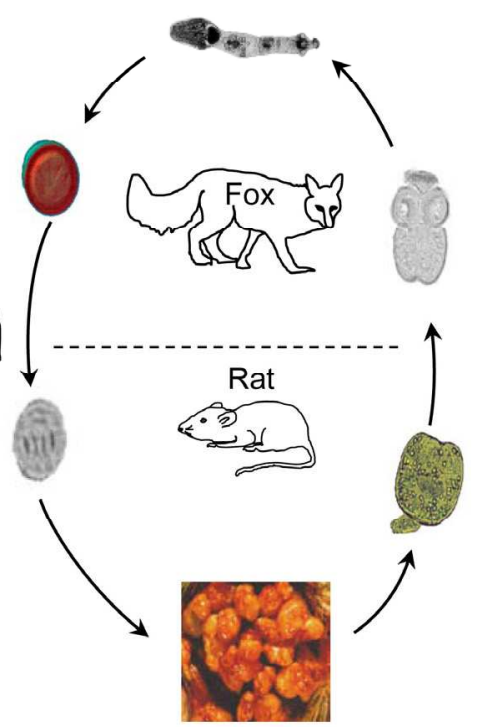

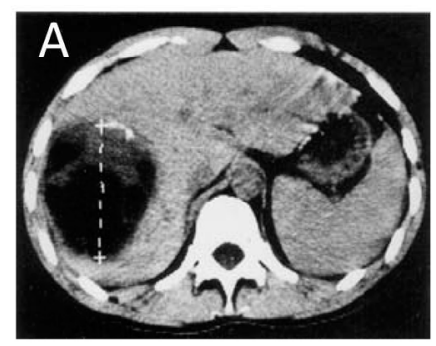
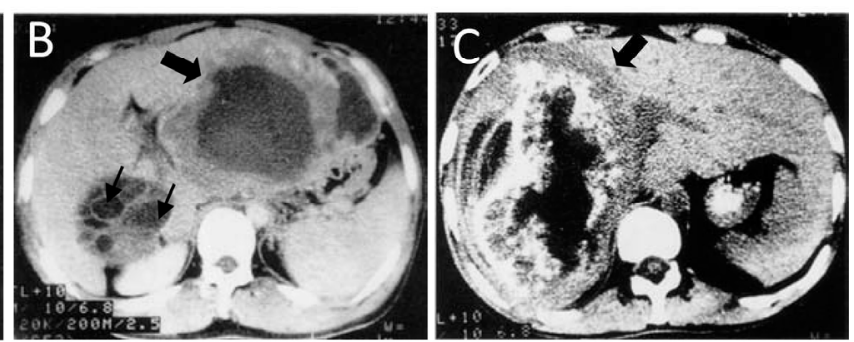

Fig. 1. Life cycle of Echinococcus (upper panel) and hepatic echinococcosis scanned by computed axial tomography (CT) (lower panels). A, Cystic echinococcosis (CE) due to E. granulosus. B, a patient infected with both $\mathrm{CE}$ (daughter cysts are marked with small arrowheads) and alveolar echinococcosis (AE, large arrowhead). C, AE due to E. multilocularis infection (arrowhead).

Intermediate hosts are herbivores such as sheep, horses, cattle, pigs, goats, camels, moose, kangaroos and wallabies. Humans are accidental hosts and generally play no part in transmission. Intermediate hosts and humans become infected by ingesting eggs of the parasites, which are released in the faeces of the definitive hosts. The eggs hatch in the gastrointestinal tract and become activated larvae (oncospheres) which penetrate the intestinal wall and enter the bloodstream, eventually locating in internal organs, where they develop into hydatid cysts. Hydatid cysts of E. granulosus develop in internal organs of intermediate hosts and humans as fluid-filled bladders (Figure 1A). The cysts can be located 
in almost all organs, with about $70 \%$ of cysts in the liver, $20 \%$ in the lungs, with the remainder involving other organs such as the kidney, spleen, brain, heart and bone.

A typical cyst of E. granulosus consists of two parasite-derived layers; an inner nucleated germinal layer and an outer acellular laminated layer surrounded by a host-produced fibrous capsule. Brood capsules and protoscoleces bud off from the germinal membrane.

The alveolar cyst or metacestode of E. multilocularis develops differently to that of $E$. granulosus, being a complex tumor-like multivesicular, infiltrating structure consisting of numerous small vesicles embedded in stroma of connective tissue (Fig 1B and C). The larval mass usually contains a semisolid matrix, rather than fluid, with granulomatous infiltration of mononuclear cells around the parasitic vesicles, a hallmark of $\mathrm{AE}$, culminating in irreversible fibrosis. Adult worm infections of E. multilocularis occur mainly in red and arctic foxes, although dogs and cats (rarely) can also act as definitive hosts. Small mammals (usually microtine and arvicolid rodents) act as intermediate hosts (Fig 1).

The chronic disease of CE is characterized in humans and domestic and wild ungulates by long term growth of metacestode (hydatid) cysts in the internal organs of intermediate hosts. Clinical manifestations are mild in the early stages of infection, and normally remain asymptomatic for a long period, but the host does produce detectable humoral and cellular responses against the infection, while the parasite has evolved highly effective evasive strategies to aid in long term survival. Immunity to E. granulosus infection is typical of a chronic infection and the host responses are pivotal for developing laboratory-based diagnostic procedures.

The proliferative larval stages of E. granulosus and E. multilocularis can 'leak" out of a ruptured cyst (E. granulosus) or metastisize (E. multilocularis) to another organ or tissue naturally producing a condition known as secondary $\mathrm{CE}$ or $\mathrm{AE}$, respectively. This also allows the parasites to be passaged serially from one intermediate host to another by intraperitoneal implantation of the larvae, simplifying the technical difficulties and danger associated with cyclic passage through both definitive and intermediate hosts.

$\mathrm{CE}$ and $\mathrm{AE}$ are both serious diseases, the latter especially so, with a poor prognosis if careful clinical management is not carried out. In the later stages of echinococcosis, as the disease progresses, the parasite may physically damage tissues and organs which can become dysfunctional and can be fatal, especially in $\mathrm{AE}$, when the parasite destroys the liver parenchyma, bile ducts and blood vessels resulting in biliary obstruction and portal hypertension. In most late-stage cases a necrotic cavity, containing viscous fluid, may form in the liver.

\section{Host immune responses against infection}

Immune responses play an important role in the host-parasite interplay in echinococcosis. The mammalian host produces immune responses to reject and/or limit the growth of the parasite, whereas, the parasite produces molecules to avoid these immune attacks. One phenomenon of the infection is self-cure, which is commonly observed in sheep (Zhang and Zhao, 1992; Cabrera et al., 2003) and also occurs in humans in hyper-endemic areas (Wang et al., 2006; Moro et al., 2005; Macpherson et al., 2004). Indeed, more than 70\% of cysts surgically removed from a large cohort of Chinese patients were shown to be inactive and 
calcified (Peng, XY, personal communication), indicating that the number of human selfcure cases can be substantial. However, details of this important, likely immunologicallybased process, remain limited. In addition, some intermediate hosts such as cattle produce a high percentage - $>90 \%$ - of cysts that are infertile in that they do not contain protoscoleces, the developmental form of the parasite infective to the definitive host (Fig. 1), with host species-specific differences in immunity probably the key factor (Zhang et al., 2003a). Similarly in AE, some patients with calcified lesions (Gottstein and Felleisen, 1995) are likely due to self-cure.

This self-cure phenomenon raises the possibility that protective immune responses against parasite growth and dissemination may exist. However, little is known about the determinants which may restrain metacestode survival and proliferation, or eliminate Echincococcus infection.

Although the data are limited, there is, nevertheless, clear evidence, from experiments with animals challenged with E. granulosus/E. multilocularis eggs or oncospheres that infected hosts produce significant immune responses, including antibody and $\mathrm{T}$ cell responses generated by lymphocytes. Understanding the mechanisms whereby these immune responses are produced, particularly the role of protective antibodies against the oncosphere, has been of fundamental importance in developing highly effective recombinant vaccines against both E. granulosus and E. multilocularis.

\subsection{Antibody responses}

The earliest immunoglobin (Ig) G response to E. granulosus hydatid cyst fluid and oncospheral antigens appears after 2 and 11 weeks, respectively, in mice and sheep challenged with eggs or oncospheres of E. granulosus (Zhang et al., 2003b; Yong et al., 1984). Anti-oncospheral antibodies play a major role in parasite killing and are central to the protective immune response against E. granulosus (Read et al., 2009). In the chronic phase of CE, elevated antibody levels, particularly IgG, IgM and IgE, occur in humans (Khabiri et al., 2006; Daeki et al., 2000; Pinon et al., 1987; Craig, 1986; Dessaint et al., 1975) (Fig. 2), with IgG1 and IgG4 being predominant (Daeki et al., 2000; Sterla et al., 1999; Wen and Craig, 1994). In murine models of AE infection, IgG and IgM were significantly increased after 9 weeks post-infection (p.i) with eggs (Matsumoto et al., 2010). Antibody responses to protoscolex antigens are relatively weak and delayed in the early stage of $E$. multilocularis infection in mice, but are increased later (Bauder et al., 1999; Matsumoto et al., 1998); IgG1 and IgG3 levels increase significantly at 8 weeks p.i, and remain elevated thereafter (Li et al., 2003a).

Antibody production is a pre-requisite for the development of serodiagnostic tests, but 30$40 \%$ of patients are antibody-negative for CE. In many of these patients, however, varying levels of circulating antigens (CAg) and circulating immune complexes (CIC) are measurable (Craig, 1993). This phenomenon suggests that B cell activity and proliferation may be regulated and inhibited by E. granulosus antigens. It is not known whether these antigens directly target $\mathrm{B}$ cells or via $\mathrm{T}$ cell regulatory mechanisms. One study showed that after infection, CD4-knockout mice and C57Bl/6 mice had similar titres of specific antibodies, indicating that antibody production may be $\mathrm{T}$ cell-independent in early infection (Baz et al., 2008). 


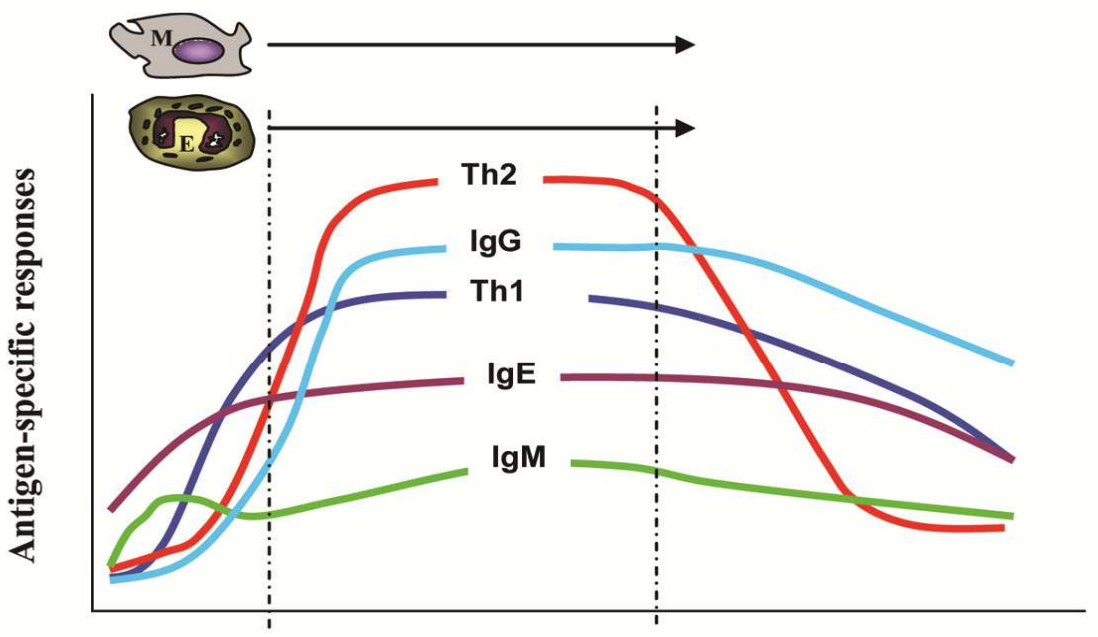

Early stage Establishment and growth Dead, dying or surgically removed cyst

\section{Development of cyst}

Fig. 2. Immune responses during the development of a hydatid cyst of E. granulosus in the intermediate host. In the early stage of infection, the oncosphere is transported to a host organ such as the liver or lung where it develops into a hydatid cyst. The immature cyst has to overcome host, mainly cell-mediated, immune responses, especially the infiltration of macrophages and eosinophils and low level polarized Th1 responses. About 8-10 weeks post-infection in mice, cyst growth is maintained and complex echinococcal antigens are released from the cyst. These antigens stimulate complex immune responses. These include polarized Th2 responses, balanced with Th1 responses. At this time, the parasite produces significant quantities of antigens that help to modulate the immune response, which may benefit both host and parasite; IgG, especially IgG1 and IgG4, IgE and IgM levels are elevated. When the cyst is dead, dying or surgically removed, the Th2 responses drop rapidly, whereas the Th1 responses drop slowly then becoming polarized. IgG can be maintained in the human host for many years after the cyst is surgically removed. Once an infected patient has relapsed, the Th2 responses recover very quickly, while other responses are elevated slowly. M, macrophage; E, eosinophil.

In addition, antibody responses may indicate the infectious status (Li et al., 2010; Delunardo et al., 2010; Reiter-Owona et al., 2009; Ben Nouir et al., 2008; Ortona et al., 2005). A survey of $246 \mathrm{CE}$ patients showed that $E$. granulosus antigen B (AgB) specific antibody was elevated in a significantly greater proportion $(87.3 \%)$ of subjects with active or transitional stage cysts (CE1, CE2, or CE3), compared with $54.8 \%$ of other patients with inactive or early stage cysts (CL, CE4 or CE5). Furthermore, AgB-specific antibody was detected in 95.6\% of CE2 cases, which was statistically higher than that (73.7\%) in CE1 patients (Li et al., 2010). Results from 173 AE patients showed that serum antibody levels against Em18 were significantly correlated with the disease phase (Li et al., 2010). 
A survey of 861 children in China showed that serological tests can also be as an indicator of Echinococcus transmission; this study predicated the transmission of echinococcosis due to changes in the ecology and socio-geography in and around endemic communities (Yang et al., 2008).

\section{2 $\mathrm{T}$ cell responses}

During the early stages of an echinococcal infection, there is a marked activation of cellmediated immunity including cellular inflammatory responses and pathological changes (Zhang et al., 2003a; Zhang et al., 2008b). Cellular infiltration of eosinophils, neutrophils, macrophages, and fibrocytes occurs in humans (Magambo et al., 1995; Peng et al., 2006) and sheep (Petrova, 1968) infections. However, this generally does not result in a severe inflammatory response and aged cysts tend to become surrounded by a fibrous layer that separates the laminated cystic layer from host tissue.

Early Th1 polarized cytokine production, which can kill the metacestode at the initial stages of development (Vuitton, 2003), then shifts to a predominant Th2 cytokine response in the later, chronic stage, and is characteristic of E. granulosus and E. multilocularis infection (Fig. 2). Very little is known of cytokine production in the early phases of a primary (oral challenge with eggs) E. granulosus infection, although both Th1 and Th2 cytokine levels are low in the early stages of a primary E. multilocularis infection, but are raised subsequently (Bauder et al., 1999). As well, it is thought the Th2 cytokines are responsible for inhibition of parasite killing because of the anti-inflammatory action of interleukin-10 (IL-10) (Bauder et al., 1999; Vuitton, 2003). The Th2-type cytokines profile in abortive AE patients was opposite to those in progressive patients, with IL -10 and IL-5 associated with the progression of disease (Godot et al., 2000). However, secondary E. multilocularis infection in a mouse model showed that Th1 cytokines play a role in resistance of parasite growth (Emery et al., 1997).

Patients with chronic CE generate both Th1 and Th2 responses (Baz et al., 2006). Given the recent advances in understanding the immunoregulatory capabilities of helminthic infections, it has been suggested that Th2 responses play a crucial role in chronic helminthiasis (Allen and Maizels, 2011). However, a remarkable feature of chronic CE infection is the coexistence of interferon-gamma (IFN- $\gamma$ ), IL-4 and IL-10 at high levels in human echinococcosis (Mezioug and Touil-Boukoffa, 2009). It is unclear why hydatid infection can induce high levels of both Th1 and Th2 cytokines (Rigano et al., 1995a) since they usually down-regulate each other (Pearce and MacDonald, 2002). Antigen and the amount of antigens released may play key roles. For instance, E. granulosus AgB skewed Th1/Th2 cytokine ratios towards a preferentially immunopathology-associated Th2 polarization, predominantly in patients with progressive disease (Rigano et al., 2001).

Liver pathology in $\mathrm{AE}$ is characterized by the presence of a huge granulomatous infiltrate of mononuclear cells involving mainly macrophages, myofibroblasts and $\mathrm{T}$ lymphocytes (Harraga et al., 2003; Vuitton et al., 1989). In the progressive forms of the disease, the T cell infiltrate within the periparasitic granuloma is mainly composed of CD8 T lymphocytes (Bresson-Hadni et al., 1990).

A hallmark of chronic Echinococcus infection is the presence of high levels of IL-10 (Zhang et al., 2008a; Vuitton, 2003), a cytokine typically associated with immunoregulation of effector responses (Moore et al., 2001). The role of IL-10 in chronic infection largely remains unclear, 
although one report showed that IL-10 may impair the Th1 protective response and allow the parasite to survive in hydatid patients (Moore et al., 2001). By inducing the host to produce high levels of IL-10, E. multilocularis appears able to modulate the immune response so that the $\mathrm{T}$ cells infiltrating the periparasitic granuloma cannot participate in the effector phase of the cellular immune response (Zhang et al., 2008a; Vuitton, 2003). The interaction of the Echinococcus organisms with their mammalian hosts may provide a highly suitable model to address some of the fundamental questions remaining such as the molecular basis underpinning the different effects of IL-10 on different cell types; the mechanisms of regulation of IL-10 production; the inhibitory role of IL-10 on monocyte/macrophage and CD4 T cell function; its involvement in stimulating the development of B cells and CD8 T cells; and its role in the differentiation and function of $\mathrm{T}$ regulatory cells.

In addition, the production of subgroups of chemokines (CC and CXC) associated with inflammation (MIP-1 alpha(macrophage inflammatory protein 1 alpha)/CCL3, MIP-1 beta/CCL4, RANTES (regulated upon activation, normally T-cell expressed and secreted)/CCL5 and GRO-alpha (growth-regulated oncogene-alpha)/CXCL1) in peripheral blood mononuclear cells stimulated with Em antigens in vitro was constitutively larger in AE patients than in controls(Kocherscheidt et al., 2008). However, in patients, Em metacestodes suppressed cellular chemokine production, and this may constitute an immune escape mechanism which reduces inflammatory host responses, prevents tissue destruction and organ damage, but may also facilitate parasite persistence (Kocherscheidt et al., 2008).

It is not known whether the significant cellular infiltration of macrophages and neutrophils occurring as the parasite develops results from the innate immune mechanisms of the host and the release of chemotactic substances by the parasite or whether it is dependent on Th0/Thl cytokines. A large number of CD4(+) T lymphocytes are present in AE patients with aborted or dead lesions, whereas patients with active parasites display a significant increase in activation of predominantly CD8(+) T cells (Manfras et al., 2002) indicating that CD4(+) T cells may play a role in the killing mechanism. This is supported by experiments undertaken with genetically modified mice (Dai et al., 2001). Conversely, E. multilocularis is able to survive and persist in its host indefinitely for long periods of time. In fact, the murine immune response fails to clear infection even when presented with the lowest possible infection dose by injection with a single parasite vesicle (Gottstein et al., 2002).

\subsection{Correlation of cytokines with antibody production}

It is noteworthy that the increased production of IL-4 and IL-10 in hydatid patients (Bayraktar et al., 2005) corresponds with high levels of IgE and IgG4 (Rigano et al., 1995b), suggesting regulation by IL-4 of IgE and IgG4 responses (Rigano et al., 2001; Rigano et al., 1995b; King and Nutman, 1993). Patients with a primary infection have higher levels of IL-2, IFN- $\gamma$ and IL-5. The effect of IL-5 on human B cells is controversial (Clutterbuck et al., 1989), but a significant correlation between IL-5 production and IgE/IgG4 expression has been found in hydatid patients (Rigano et al., 1996), indicating that IL-5 is associated with the regulation of specific IgE/IgG4 expression. When CE cysts grow, IgG1 and IgG4 levels are elevated, whereas the concentrations of specific IgG1 and IgG4 decline in cases characterized by cyst infiltration or calcification. This indicates that the IgG4 antibody 
response is also associated with cystic development, growth and disease progression, whereas the IgG1, IgG2 and IgG3 responses occur predominantly when cysts become infiltrated or are destroyed by the host (Daeki et al., 2000).

\section{4 $\mathrm{T}$ cell responses and treatment}

The polarized $\mathrm{T}$ cell responses in echinococcosis have been shown to be modulated by the developmental status of the hydatid cyst, as shown by experiments with T-cell lines generated from patients with active, transitional and inactive hydatid cysts and stimulated with sheep hydatid fluid antigens. It is likely due to the antigens containing distinct epitopes for each T-cell subset as a single recombinant protein can stimulate both types of response (Zhang et al., 2003a). T-cell lines from a patient with an inactive cyst had a Th1 profile, while T-cell lines derived from patients with active and transitional hydatid cysts had mixed Th1/Th2 and Th0 clones (Rigano et al., 2004), indicating that Th1 lymphocytes contribute significantly to the inactive stage of hydatid disease, with Th2 lymphocytes being more important in the active and transitional stages. When CE patients were drug-treated with albendazole/mebendazole, a Th1 cytokine profile, rather than a Th2 profile, typically dominated, indicating that Th1 responses have a role in the process of cyst degeneration (Rigano et al., 1995b). An increased Th1-type cytokine IFN- $\gamma$ response has been suggested as a marker for monitoring AE patient treatment (Dvoroznakova et al., 2004), whereas as measurement of serum IL-4 may be a useful marker for the follow up of patients with CE (Rigano et al., 1999b).

One aspect that is likely to be important in the control of such immunological mechanisms is the influence of CD4+ T-helper lymphocytes as they may impact on treatment of echinococcosis (Vuitton, 2004). As indicated earlier, self-cure is a common feature of CE infection in sheep (Zhang and Zhao, 1992; Cabrera et al., 2003), and it most likely also happens in human populations in hyper-endemic areas as patients with calcified cysts are often reported (Moro et al., 2005; Macpherson et al., 2004). Cytokines are likely to play a key role in the process of self-cure and this is an important area that needs further research.

Both in vitro and in vivo studies have shown that high levels of the Th1 cytokine IFN- $\gamma$ were found in patients who responded to chemotherapy, whereas high levels of Th2 cytokines 1 (IL-4 and IL-10) occurred in patients who did not (Rigano et al., 1999b; Rigano et al., 1999a; Rigano et al., 1995b; Rigano et al., 1995a).

\subsection{Dendritc cells}

Some recent studies have focused on dendritic cells (DC) and their regulation on other immune responses in CE. E. granulosus antigens influence maturation and differentiation of DC stimulated with lipopolysaccharide (LPS) (Kanan and Chain, 2006). This includes downmodulation of CD1a expression and up-regulation of CD86 expression, a lower percentage of CD83(+) cells being present, and down-regulation of interleukin-12p70 (IL-12p70) and TNF alpha (Rigano et al., 2007). In addition, hydatid cyst fluid (HCF) modulates the transition of human monocytes to DC, impairs secretion of IL-12, IL-6 or PGE2 in response to LPS stimulation, and modulates the phenotype of cells generated during culture, resulting in increased CD14 expression (Kanan and Chain, 2006). AgB has been shown to induce IL-1 receptor-associated kinase phosphorylation and activate nuclear factor-kappa B, 
suggesting that Toll-like receptors could participate in E. granulosus-stimulated DC maturation (Rigano et al., 2007).

E. multilocularis infection in mice induced DC expressing high levels TGF and very low levels of IL-10 and IL-12, and the expression of the surface markers CD80, CD86 and CD40 was down-regulated (Mejri et al., 2011a; Mejri et al., 2011b). However, the higher level of IL-4 than IFN- $\gamma /$ IL-2 mRNA-expression in AE-CD4+ pT cells indicated DC play a role in the generation of a regulatory immune response (Mejri et al., 2011a).

Different E. multilocularis antigens have been shown to stimulate different expression profiles of DC. Em14-3-3-antigen induced CD80, CD86 and MHC class II surface expression, but Em2(G11) failed to do so. Similarly, LPS and Em14-3-3 yielded elevated IL-12, TNF-I+/and IL-10 expression levels, while Em2(G11) did not. The proliferation of bone marrow DC isolated from AE-diseased mice was abrogated (Margos et al., 2011), indicating the E. multilocularis infection inhibited T cell responses.

\subsection{Regulatory T cells}

Chronic Echinococcus infection results in the suppression of host immune responses, allowing long-term parasite survival and restricting pathology. Current theories suggest that regulatory $\mathrm{T}$ cells (Treg) play an important role in this regulation. However, the mechanism of Treg induction during Echinococcus infection is still unknown, although several studies have focused on this area.

A subpopulation of regulatory CD4+ CD25+ T cells isolated from E. multilocularis-infected mice reduced ConA-driven proliferation of CD4+ pT cells. The high expression levels of Foxp3 mRNA by CD4+ and CD8+ peritoneal $\mathrm{T}$ cells suggested that subpopulations of regulatory $\mathrm{CD} 4+$ Foxp3+ and $\mathrm{CD} 8+$ Foxp3 $+\mathrm{T}$ cells were involved in modulating the immune responses in the chronic stage of $\mathrm{AE}$, which are Th2 polarized responses (Mejri et al., 2011b).

A primary infection with oncospheres of E. granulosus in mice (Zhang et al., 2001) generated a low level antibody response during the first 8 weeks (Zhang et al., 2003b), possibly indicating host immunosuppression. After 9 weeks of the primary infection, antibodies against hydatid cyst fluid and oncosphere antigens were significantly increased, suggesting that antibody production during the course of the infection may be regulated, perhaps through periodic release of antigen from cysts and/or general down regulation of B-cells through T-helper cell activity.

$\mathrm{AgB}$ is the most evaluated echinococcal antigen for its role in modulation of immune responses. AgB significantly inhibits polymorphonuclear cell recruitment (Rigano et al., 2001; Shepherd et al., 1991), modulates dendritic cell differentiation and polarizes immature DC maturation towards a Th2 cell response (Rigano et al., 2007). After establishment in the host, the hydatid cyst produces a large amount of AgB (Zhang et al., $2003 b)$, which can alter the Th1/Th2 ratio from a predominant Th1 response in the early stage of infection to a Th2 response (Rigano et al., 2001), indicating that AgB is a modulator of the $\mathrm{T}$ cell response benefiting parasite survival. A number of studies have shown that $\mathrm{AgB}$ is encoded by a gene family and the antigen exhibits a high degree of 
genetic polymorphism (Haag et al., 2006; Rosenzvit et al., 2006; Kamenetzky et al., 2005), suggesting that the Echinococcus organisms have evolved antigenic variation-type mechanisms for escaping the host immune response.

\section{Serological diagnosis of human echinococcosis}

Typical asymptomatic features in the early stages of infection and for a long period after establishment makes early diagnosis of echinococcosis in humans difficult. Although the definitive diagnosis for most human cases of CE is by physical imaging methods, such as Xray, ultrasonography, computed axial tomography (CT scanning) and magnetic resonance imaging, these procedures are often not readily available in isolated communities and usually they provide effective diagnosis mainly of the late development stages of clinical infection. Early diagnosis of CE and AE by serology may, therefore, provide opportunities for early treatment and more effective chemotherapy. Another practical application of serology in human echinococcosis is the follow-up of the treatment. Although hydatid disease is an asymptomatic infection, the host does produce detectable humoral and cellular responses against the infection. Measurement of these responses is a prerequisite for developing effective serodiagnostic tools.

\subsection{Methodology in detecting antibodies}

Almost all serological tests have been developed for immunodiagnosis of human CE cases. These include indirect haemagglutination (IHA), latex agglutination (LA), complement fixation test (CFT), immunoelectrophoresis (IEP) tests and enzyme-linked immunosorbent assay (ELISA) (Rickard et al., 1984; Rickard, 1984). In contrast, the CFT and LA tests are more likely to give non-specific or false positive reactions (Rickard, 1984) as is the IHA test when serum titres are lower than 1:512 (Varela-Diaz et al., 1975c; Varela-Diaz et al., 1975b; VarelaDiaz et al., 1975a; Craig and Nelson, 1984).

There are considerable differences between the various tests both in specificity and sensitivity. As the sensitivity of a test increases, so generally does the demand for improved antigens in order that sufficient specificity can be achieved to take advantage of the greater sensitivity. An optimum test should be specific with high sensitivity. Insensitive and nonspecific tests including the Cassoni intradermal test, CFT, IHA and LA test have been replaced by ELISA, IEP, indirect immunofluorescence antibody test (IFAT), and immunoblotting (IB) in routine laboratory application (Lightowlers and Gottstein, 1995; Nasrieh and Abdel-Hafez, 2004)). ELISA achieved sensitivity rates of 88 to $98 \%$ using cyst fluid preparations (Rickard et al., 1984; Speiser, 1980).

Recently developed dipstick assays (van Doorn et al., 2007) are considered to be valuable methods for CE serodiagnosis. A dipstick assay has been developed that exhibited 100\% sensitivity and $91.4 \%$ specificity with 26 CE sera and 35 other parasite infection sera using camel hydatid cyst fluid as antigen (Al-Sherbiny et al., 2004). Since the dipstick assay is extremely easy to perform with a visually interpreted result within $15 \mathrm{~min}$, in addition to being both sensitive and specific, the test could be an acceptable alternative for use in clinical laboratories lacking specialized equipment and the technological expertise needed for IB or ELISA. 
One study (Ortona et al., 2000) highlights the need to standardize techniques and antigenic preparations and to improve the performance of immunodiagnosis by characterizing new antigens and detecting distinct immunoglobulin classes. The diagnostic sensitivity and specificity of IEP, ELISA and IB, in detecting IgG antibodies in patient sera to native and recombinant $\mathrm{AgB}$ and a hydatid fluid fraction (HFF) were compared. Sera tested were from patients who had CE grouped according to their type of cysts, from patients with other parasitic diseases, lung or liver carcinomas or serous cysts, and from healthy controls. HFFIB gave the highest sensitivity $(80 \%)$ followed by ELISA $(72 \%)$ and IEP $(31 \%)$. The diagnostic sensitivity significantly decreased as cysts matured (from type I-II to type VII, classified by ultrasound). Recombinant and native AgB-IB yielded similar sensitivity (74\%) but a large number of clinically or surgically confirmed CE patients $(20 \%)$ were negative. In these patient sera, IB to assess the usefulness of another recombinant E. granulosus molecule (elongation factor-1 beta/delta) in detecting IgE antibodies, yielded 33\% of positivity.

The results of this and other studies suggest that hydatid serology may be improved by combining several defined antigens (including synthetic peptides), and the design of new $E$. granulosus-specific peptides that react with otherwise false-negative sera.

\subsection{Immunodiagnosis of cystic echinococcosis in humans}

The immunodiagnosis of echinococcosis has been comprehensively reviewed (Zhang et al., 2003a). Over the past decade, diagnosis of CE has improved due to the use of new or more optimal methods for purification of Echinococcus antigens from somatic materials, by the application of molecular tools for parasite identification and the synthesis of recombinant diagnostic antigens and immunogenic peptides. These approaches have not only improved the sensitivity and specificity of tests for diagnosis of CE but they have also allowed more reliable characterization of the biological status of parasite materials (Zhang and McManus, 2006; Siles-Lucas and Gottstein, 2001).

The long history of CE serodiagnosis has mainly involved the identification and characterization of specific E. granulosus antigens. The lipoproteins antigen B (AgB) and antigen 5 (Ag5), the major components of HCF, have been the two molecules that have received wide attention in regards to diagnosis. Both antigens have been well characterized in terms of their molecular features and diagnostic potential (Zhang et al., 2003a). Although AgB and Ag5 have proved to be diagnostically valuable, there are difficulties related to their lack of sensitivity and specificity and problems with the standardization of their use. Cross-reactivity with antigens from other parasites, notably other taeniid cestodes, is a major problem. IgE cross-reaction with other parasites (Wattal et al., 1988; Force et al., 1992) is common.

Data in the literature for sensitivity and cross-reactivity of serum anti-Echinococcus IgE differ significantly; most studies report high specificity (99-100\%) (Marinova et al., 2011; Chamekh et al., 1992; Khabiri et al., 2006; Afferni et al., 1984; Sjolander et al., 1989; Zarzosa et al., 1999)

A recent study using a large panel of sera showed that crude or purified antigens from parasite or hydatid cyst fluid generated a reasonable high specificity (Feng et al., 2010). By using 857 sera from confirmed CE patients and 42 sera from AE patients and 697 sera with different infection and medical conditions showed an overall of $93.4 \%$ of specificity with relative low sensitivity 57.4-68.4\% (Table 1) (Feng et al., 2010). 


\begin{tabular}{|c|c|c|c|c|c|c|c|}
\hline \multirow[t]{2}{*}{ Antigen } & \multirow[t]{2}{*}{ Test } & \multicolumn{3}{|c|}{ Number of subjects tested } & \multicolumn{2}{|c|}{$\begin{array}{c}\text { Sensitivity (\%)Specificity } \\
(\%)\end{array}$} & \multirow[t]{2}{*}{ Reference } \\
\hline & & CE & Healthy & $\begin{array}{c}\text { Other } \\
\text { diseases }\end{array}$ & & & \\
\hline$\overline{\mathrm{HBLF}}$ & LA & 119 & 37 & 54 & 86 & 87.9 & (Barbieri et al., 1993) \\
\hline HFF & IHA & 204 & 90 & 53 & 54 & 100 & (Ortona et al., 2000) \\
\hline $\mathrm{HFF}$ & IgE IB & 204 & 90 & 53 & 80 & 96 & (Ortona et al., 2000) \\
\hline HFF & IEP & 204 & 90 & 53 & 31 & 100 & (Ortona et al., 2000) \\
\hline $\mathrm{HCF}$ & IgG ELISA & 71 & 45 & 62 & 64 & 80 & (Verastegui et al., 1992) \\
\hline FBHCF & IgG ELISA & 119 & 37 & 54 & 83 & 86.8 & (Barbieri et al., 1993) \\
\hline sWHF & IgG ELISA & $111 / \mathrm{Li}$ & 0 & 0 & 89 & nd & (Babba et al., 1994) \\
\hline sWHF & IgG ELISA & 122/Lu & 0 & 0 & 78 & nd & (Babba et al., 1994) \\
\hline FBHCF & IgG ELISA & 90 & 28 & 88 & 84 & 60 & (Barbieri et al., 1998) \\
\hline $\mathrm{HCF}$ & IgG ELISA & 87 & 200 & 339 & 94 & 82.3 & (Poretti et al., 1999) \\
\hline $\mathrm{HCF}$ & IgG ELISA & 42 & 15 & 41 & 81 & 95 & (Irabuena et al., 2000) \\
\hline $\mathrm{HFF}$ & IgG ELISA & 204 & 90 & 53 & 72 & 97 & (Ortona et al., 2000) \\
\hline ppHCF & IgG ELISA & 70 & 30 & 73 & 89 & 40.8 & (Jiang et al., 2001) \\
\hline $\mathrm{HCF}$ & IgG ELISA & 129 & 203 & 65 & 78 & 97 & (Virginio et al., 2003) \\
\hline $\mathrm{HCF}$ & IgG ELISA & 59 & 15 & 55 & 79 & 73 & (Lorenzo et al., 2005) \\
\hline $\mathrm{HCF}$ & IgG ELISA & 26 & 10 & 45 & 96 & 100 & (Al-Sherbiny et al., 2004) \\
\hline $\mathrm{HCF}$ & IgG Dip & 26 & 10 & 45 & 100 & 91 & (Al-Sherbiny et al., 2004) \\
\hline $\mathrm{HCF}$ & IgG WB & 71 & 45 & 62 & 65 & 91 & (Verastegui et al., 1992) \\
\hline HCF AgB & IgG Dot-IB & 875 & 5 & 739 & 68.4 & 93.4 & (Feng et al., 2010) \\
\hline HCF AgB & IgG ELISA & 857 & 5 & 739 & 57.4 & 93.4 & (Feng et al., 2010) \\
\hline HCF AgB & IgE WB & 324 & 70 & 500 & 86.4 & 92 & (Li et al., 2003b) \\
\hline $\mathrm{HCF}$ & IgG WB & 26 & 10 & 45 & 100 & 91 & (Al-Sherbiny et al., 2004) \\
\hline $\mathrm{HCF}$ & $\begin{array}{l}\operatorname{IgE} \\
\operatorname{ImCAP}\end{array}$ & 155 & 110 & 58 & 73.6 & 99.1 & (Marinova et al., 2011) \\
\hline $\mathrm{HCF}$ & IgG ELISA & 155 & 110 & 58 & 90.3 & 90.9 & (Marinova et al., 2011) \\
\hline $\mathrm{HCF}$ & IgG WB & 155 & 110 & 58 & 90.1 & 94.5 & (Marinova et al., 2011) \\
\hline
\end{tabular}

Table 1. Features of assays for immunodiagnosis of cystic echinococcosis based on hydatid cyst fluid antigens and native proteins from E. granulosus Abbreviations: HFF - hydatid fluid fraction, rich in Ag5 and AgB; HBLF - heparin-binding lipoprotein fraction; ppHCF partially purified HCF; FBHCF - fertile bovine hydatid cyst fluid; Li - liver; Lu - lung; sWHF - sheep whole hydatid cyst fluid; IHA - indirect haemagglutination assay; LA - Latex agglutination assay; IEP - immunoelectrophoresis; ELISA - enzyme - linked immunosorbent assay; WB - Western blotting; Dip, dipstick; ImCAP, immunoCAP system.

\subsubsection{E. granulosus antigen $B$}

E. granulosus antigen B (AgB), a polymeric lipoprotein with a molecular weight of $120 \mathrm{kDa}$, is a highly immunogenic molecule, a characteristic that underpins its value in serodiagnosis (Table 2). AgB can be measured in patient blood as circulating antigen (Kanwar et al., 1994; Kanwar and Kanwar, 1994; Liu et al., 1993). It has a molecular size of circa $8 \mathrm{kDa}$ on sodium dodecyl sulfate polyacrylamide gel electrophoresis (SDS-PAGE) (Lightowlers et al., 1989; Shepherd and McManus, 1987) under reduced conditions. The function of AgB in the parasite's biology is not completely elucidated, but several studies have shown that the molecule may be involved in the modulation of the host immune response; for instance, as a protease inhibitor that inhibits neutrophil chemotaxis (Shepherd et al., 1991; Virginio et al., 2007), promoting a non-protective Th2 response by interfering with monocyte differentiation, and by modulating DC maturation (Kanan and Chain, 2006; Rigano et al., 2007). One study has suggested that AgB could be involved in the processes of lipid uptake or detoxification (Chemale et al., 2005). 


\begin{tabular}{|c|c|c|c|c|c|c|c|}
\hline \multirow[t]{2}{*}{$\overline{\mathrm{AgB}}$} & \multirow[t]{2}{*}{ Test } & \multicolumn{3}{|c|}{ Number of subjects tested } & \multirow{2}{*}{$\begin{array}{l}\text { Sensitivity } \\
(\%)\end{array}$} & \multirow{2}{*}{$\begin{array}{l}\text { Specificity } \\
(\%)\end{array}$} & \multirow[t]{2}{*}{ Reference } \\
\hline & & $\mathrm{CE}$ & Healthy & $\begin{array}{c}\text { Other } \\
\text { diseases }\end{array}$ & & & \\
\hline$\overline{\text { Gel-EF }}$ & IgG ELISA & 204 & 90 & 53 & 74 & 100 & (Ortona et al., 2000) \\
\hline $\mathrm{pp}$ & IgG ELISA & 90 & 28 & 86 & 77 & 85 & $\begin{array}{l}\text { (Gonzalez-Sapienza et } \\
\text { al., 2000) }\end{array}$ \\
\hline pp & IgG ELISA & 191 & 50 & 133 & 79 & 98 & (Shambesh et al., 1997) \\
\hline pp & IgG ELISA & 81 & - & 98 & 89 & 86 & (Wen and Craig, 1994) \\
\hline AEC & IgG ELISA & 31 & 29 & 87 & 77 & 82 & (Rott et al., 2000) \\
\hline $\mathrm{mAb}-\mathrm{AP}$ & IgG ELISA & 90 & 28 & 88 & 77 & 86 & (Barbieri et al., 1998) \\
\hline $\mathrm{pp}$ & $\begin{array}{l}\text { IgG1 } \\
\text { ELISA }\end{array}$ & 81 & - & 98 & 58 & 92 & (Wen and Craig, 1994) \\
\hline $\mathrm{pp}$ & $\begin{array}{l}\text { IgG1 } \\
\text { ELISA }\end{array}$ & 191 & 50 & 133 & 57 & 100 & (Shambesh et al., 1997) \\
\hline $\mathrm{pp}$ & $\begin{array}{l}\text { IgG2 } \\
\text { ELISA }\end{array}$ & 81 & - & 98 & 53 & 94 & (Wen and Craig, 1994) \\
\hline $\mathrm{pp}$ & $\begin{array}{l}\text { IgG3 } \\
\text { ELISA }\end{array}$ & 81 & - & 98 & 46 & 95 & (Wen and Craig, 1994) \\
\hline $\mathrm{pp}$ & $\begin{array}{l}\text { IgG4 } \\
\text { ELISA }\end{array}$ & 210 & 47 & 79 & 63 & 81 & (McVie et al., 1997) \\
\hline pp & $\begin{array}{l}\text { IgG4 } \\
\text { ELISA }\end{array}$ & 191 & 50 & 133 & 38 & 99 & (Shambesh et al., 1997) \\
\hline $\mathrm{pp}$ & $\begin{array}{l}\text { IgG4 } \\
\text { ELISA }\end{array}$ & 81 & - & 98 & 73 & 91 & (Wen and Craig, 1994) \\
\hline $\mathrm{pp}$ & $\begin{array}{l}\text { IgG4 } \\
\text { ELISA }\end{array}$ & 210 & 47 & 79 & 63 & 81 & (McVie et al., 1997) \\
\hline $\mathrm{AgB}$ & IgG ELISA & 129 & 203 & 65 & 60 & 93 & (Virginio et al., 2003) \\
\hline $\mathrm{AgB}$ & IgG ELISA & 36 & 36 & - & 91.7 & 97.2 & (Kalantari et al., 2010) \\
\hline $\mathrm{AgB}$ & IgG ELISA & 59 & 15 & 55 & 80 & 77 & (Lorenzo et al., 2005) \\
\hline $\mathrm{AgB}$ & IgG ELISA & 40 & 70 & 40 & 92 & 97 & (Sadjjadi et al., 2007) \\
\hline $\mathrm{pp}$ & $\begin{array}{l}\text { IgG } \\
\text { dELISA }\end{array}$ & 210 & 47 & 79 & 93 & 65 & (McVie et al., 1997) \\
\hline $18 \mathrm{kDa}$ & IgG WB & 69 & 82 & 63 & 10 & 77 & (Jiang et al., 2001) \\
\hline $8 \mathrm{kDa}$ & IgG WB & 35 & 200 & 339 & 71 & 97 & (Poretti et al., 1999) \\
\hline $8 \mathrm{kDa}$ & IgG WB & $52 p$ & 200 & 339 & 60 & 97 & (Poretti et al., 1999) \\
\hline $8-34 \mathrm{kDa}$ & IgG WB & 173 & 29 & $66(\mathrm{AE})$ & 85 & 65 & (Ito et al., 1999) \\
\hline $8-34 \mathrm{kDa}$ & IgG WB & 35 & 200 & 339 & 91 & 94 & (Poretti et al., 1999) \\
\hline $8-34 \mathrm{kDa}$ & IgG WB & $52 p$ & 200 & 339 & 81 & 94 & (Poretti et al., 1999) \\
\hline Gel-EF & IgG WB & 204 & 90 & 53 & 66 & 100 & (Ortona et al., 2000) \\
\hline $\mathrm{pp}$ & IgG WB & 158 & 29 & 152 & 92 & 69 & (Ito et al., 1999) \\
\hline pp & IgG WB & 173 & 29 & 115 & 92 & 100 & (Ito et al., 1999) \\
\hline $8 \mathrm{kDa}$ & IgG WB & 44 & - & 43 & 47.7 & 51.2 & (de la Rue et al., 2010) \\
\hline $16 \mathrm{kDa}$ & IgG WB & 44 & - & 43 & 45.5 & 67.4 & (de la Rue et al., 2010) \\
\hline $24 \mathrm{kDa}$ & IgG WB & 44 & - & 43 & 68.2 & 62.8 & (de la Rue et al., 2010) \\
\hline
\end{tabular}

Table 2. Features of assays for immunodiagnosis of cystic echinococcosis using native antigen B Abbreviations: Gel-EF - eluted fractions from SDS-PAGE; pp - partial purification; $\mathrm{AEC}$ - anion exchange chromatography; $\mathrm{mAb}$ - AP - affinity purification by monoclonal antibody; 52p - days post-surgery; AE - alveolar echinococcosis; ELISA - enzyme - linked immunosorbent assay; dELISA - dot - ELISA; WB - Western blot.

$\mathrm{AgB}$ is a gene family containing at least 10 genes in 5 subfamilies (Shepherd et al., 1991; Fernandez et al., 1996; Chemale et al., 2001; Arend et al., 2004; Mamuti et al., 2007; Zhang et 
al., 2010), which are differentially expressed in different stages of E. granulosus (Mamuti et al., 2007; Zhang et al., 2010). Several AgB cDNAs, such as $\mathrm{rAgB8} / 1$ and $\mathrm{rAgB8} / 2$, have been cloned, expressed as recombinant proteins and used for diagnosis. AgB8/2 provided the highest diagnostic sensitivity (84-93.1\%) and specificity (98-99.5\%) (Rott et al., 2000; Virginio et al., 2003). Furthermore, the IgG4 response against AgB appears to be the subclass of choice for serological testing (Siracusano et al., 2004).

The sensitivity and specificity of native E. granulosus cyst fluid antigens and native and recombinant AgB are shown in Tables 1-3. These studies used small panel of sera and

\begin{tabular}{|c|c|c|c|c|c|c|c|}
\hline \multirow[t]{2}{*}{ Antigen } & \multicolumn{5}{|c|}{$\begin{array}{c}\text { Assay method Number of subjects testedSensitivity } \\
(\%)\end{array}$} & \multirow[t]{2}{*}{$\begin{array}{l}\text { Specificity } \\
(\%)\end{array}$} & \multirow[t]{2}{*}{ Reference } \\
\hline & & CE & Healthy & $\begin{array}{c}\text { Other } \\
\text { diseases }\end{array}$ & & & \\
\hline$\overline{\mathrm{rAgB} . M B P}$ & IgG4 ELISA & 210 & 47 & 79 & 65 & 91 & (McVie et al., 1997) \\
\hline EG55-GST & IgG ELISA & 64 & 39 & 105 & 89 & 72 & (Helbig et al., 1993) \\
\hline $\mathrm{rAgB8} / 1$ & IgG ELISA & 31 & 29 & 87 & 55 & 80 & (Rott et al., 2000) \\
\hline $\mathrm{rAgB} 8 / 2$ & IgG ELISA & 31 & 29 & 87 & 84 & 98 & (Rott et al., 2000) \\
\hline rEgPS-3-GST & IgG ELISA & 119 & 44 & 123 & 74 & 87 & $\begin{array}{l}\text { (Leggatt and McManus, } \\
\text { 1994) }\end{array}$ \\
\hline P176 & IgG ELISA & 90 & 28 & 86 & 80 & 93 & $\begin{array}{l}\text { (Gonzalez-Sapienza et al., } \\
\text { 2000) }\end{array}$ \\
\hline P175 & IgG ELISA & 90 & 28 & 86 & 49 & 94 & $\begin{array}{l}\text { (Gonzalez-Sapienza et al., } \\
\text { 2000) }\end{array}$ \\
\hline P177 & IgG ELISA & 90 & 28 & 86 & 38 & 92 & $\begin{array}{l}\text { (Gonzalez-Sapienza et al., } \\
\text { 2000) }\end{array}$ \\
\hline P65 & IgG ELISA & 90 & 28 & 86 & 44 & 96 & $\begin{array}{l}\text { (Gonzalez-Sapienza et al., } \\
\text { 2000) }\end{array}$ \\
\hline pGu4 & IgG ELISA & 90 & 28 & 86 & 18 & 98 & $\begin{array}{l}\text { (Gonzalez-Sapienza et al., } \\
\text { 2000) }\end{array}$ \\
\hline pGU4 & IgG ELISA & 31 & 29 & 87 & 26 & - & (Rott et al., 2000) \\
\hline p65\# & IgG ELISA & 90 & 28 & 88 & $34-48$ & $80-97$ & (Barbieri et al., 1998) \\
\hline pGU4\# & IgG ELISA & 90 & 28 & 88 & $12-18$ & $96-100$ & (Barbieri et al., 1998) \\
\hline rAgB.MBP & IgG dELISA & 210 & 47 & 79 & 74 & 88 & (McVie et al., 1997) \\
\hline p65 & IgG dELISA & 25 & 9 & 8 & 64 & 100 & $\begin{array}{l}\text { (Leggatt and McManus, } \\
\text { 1994) }\end{array}$ \\
\hline rAgB-GST & IgG WB & 204 & 90 & 53 & 72 & 100 & (Ortona et al., 2000) \\
\hline P176 & IgG ELISA & 59 & 15 & 55 & 63 & 82 & \\
\hline rAgB1 & & 59 & 15 & 55 & 68 & 88 & (Lorenzo et al., 2005) \\
\hline rAgB1 & IgG ELISA & 102 & 95 & 68 & 88.2 & 80.9 & $\begin{array}{l}\text { (Hernandez-Gonzalez et } \\
\text { al., 2008) }\end{array}$ \\
\hline rAgB2 & IgG ELISA & 102 & 95 & 68 & 91.2 & 93 & $\begin{array}{l}\text { (Hernandez-Gonzalez et } \\
\text { al., 2008) }\end{array}$ \\
\hline rAgB-GST & IgG IB & 120 & 24 & 97 & 79.2 & 81 & (Lv et al., 2009) \\
\hline rAgB & IgG ELISA & 246 & & 173 & 77.6 & & (Li et al., 2010) \\
\hline
\end{tabular}

Table 3. Features of assays for immunodiagnosis of cystic echinococcosis based on using recombinant antigen B and antigen B peptides Abbreviations: ELISA - enzyme-linked immunosorbent assay; dELISA - dot enzyme - linked immunosorbent assay; ELISAs sandwich ELISA; rEgPS - recombinant protoscolex protein; GST- glutathione $S$-transferase; $\mathrm{rAgB}$ - recombinant antigen $\mathrm{B} ; \mathrm{MBP}$ - maltose binding protein; \# - coated with different buffer; WB-Western blot 
showed generally both high sensitivity and specificity (Tawfeek et al., 2011; Kalantari et al., 2010; Abdi et al., 2010; Lv et al., 2009; Sadjjadi et al., 2007; Virginio et al., 2003). Crossreactions, mainly with sera from $\mathrm{AE}$ patients, have been reported to be up to $47.7 \%$ (de la Rue et al., 2010).

In addition, a number of AgB peptides have been synthesized and used in ELISA for diagnostic purposes (Table 3). Peptide antigens have been considered as a way to enhance specificity and efforts have been made to define discrete epitopes of AgB and other molecules that could be mimicked by synthetic peptides. However, a double-blind, randomized multicenter comparison of the diagnostic performance of six major antigens (namely, $\mathrm{HCF}$, native $\mathrm{AgB}$, two recombinant $\mathrm{AgB}$ subunits, an $\mathrm{AgB}$-derived synthetic peptide, and recombinant cytosolic malate dehydrogenase) against the same serum collection showed the AgB-derived synthetic peptide provided relatively poor specificity, with instead, one of the recombinant $\mathrm{AgB}$ subunits $(\mathrm{AgB} 8 / 1)$ being recommended as the standard antigen for laboratory analysis (Lorenzo et al., 2005).

\subsubsection{E. granulosus antigen 5}

E. granulosus antigen 5 (Ag5) is a very high molecular weight (approximately $400 \mathrm{kDa}$ ) lipoprotein complex composed of $57-$ and $67-\mathrm{kDa}$ components that, under reducing conditions, dissociate into 38- and 22- to 24-kDa subunits in SDS-PAGE. Historically, one of the most used immunodiagnostic procedures for CE was the demonstration of serum antibodies precipitating antigen 5 (arc 5 ) by immunoelectrophoresis or similar techniques. Table 4 shows the performance of antigen 5 for serological diagnosis of human CE. Loss of sugar determinants on antigen 5 can reduce the antigenicity of the native protein (Lorenzo et al., 2005a). The potential value of specific antibodies of different IgG subclasses and IgE in serological diagnosis of CE using an ELISA based on Ag5 has been evaluated (Khabiri et al., 2006). The presence of IgG1 was demonstrated in all sera from 58 patients with CE. The most discriminatory and specific antibodies found in this study were IgG4 and IgE. Only one false-positive reaction was observed with IgG4 and no IgE cross-reactivity occurred with 40 sera from healthy controls. In 36 sera from patients with parasitic diseases other than $\mathrm{CE}$, two false-positive reactions with IgG4 were observed but none occurred with IgE. In immunoblotting, it was shown that the IgG1 subclass was responsible for cross-reactivity of human antibodies that reacted with the $38 \mathrm{kDa}$ subunit of Ag5. IgG4 and IgE antibodies could not recognize the $38 \mathrm{kDa}$ subunit and under non-reducing conditions reacted with the $57 \mathrm{kDa}$ subunit without any cross-reactivity with other parasites. These results demonstrated that IgG4 and IgE are the most important antibodies for serological diagnosis of CE in an Ag5-based immunoassay system. Like AgB, Ag5 has been cloned, expressed and tested for diagnostic performance but the recombinant protein showed low sensitivity (Table 4).

\subsubsection{Other recombinant proteins and approaches for immunodiagnosis}

Table 4 lists the diagnostic performance of some other recombinant E. granulosus proteins cloned recently. Li et al. (2003b) cloned a fragment designated as EpC1 and tested 896 human serum samples including 324 sera samples from patients with CE, 172 from patients with neurocysticercosis, 89 from patients with AE, and 241 from patients with other infections or clinical presentations, as well as 70 from confirmed-negative control subjects. 


\begin{tabular}{|c|c|c|c|c|c|c|c|}
\hline \multirow[t]{2}{*}{ Antigen } & \multirow[t]{2}{*}{ Test } & \multicolumn{3}{|c|}{ Number of objects tested } & \multirow[b]{2}{*}{$\begin{array}{c}\text { Sensitivity } \\
(\%)\end{array}$} & \multirow[b]{2}{*}{$\begin{array}{c}\text { Specificity } \\
(\%)\end{array}$} & \multirow{2}{*}{ Reference } \\
\hline & & CE & Heathy & $\begin{array}{c}\text { Other } \\
\text { disease }\end{array}$ & & & \\
\hline Arc5 & IEP & 35 & 200 & 289 & 63 & 97.2 & (Poretti et al., 1999) \\
\hline Arc5 & IEP & $52 p^{*}$ & 200 & 289 & 58 & 97.2 & (Poretti et al., 1999) \\
\hline $\mathrm{mAb}-\mathrm{AP}$ & IgG ELISA & 90 & 28 & 88 & 50 & 92 & (Barbieri et al., 1998) \\
\hline mAb-AP & IgG ELISA & 39 & 29 & 51 & 54 & 89 & (Gonzalez et al., 2000) \\
\hline P89-122\# & IgG ELISA & 90 & 28 & 88 & $14-21$ & $77-100$ & (Barbieri et al., 1998) \\
\hline rP-29 & IgG ELISA & 39 & 29 & 51 & 61 & 80 & (Gonzalez et al., 2000) \\
\hline P89-122\# & IgG ELISA & 39 & 29 & 51 & 44 & 100 & (Gonzalez et al., 2000) \\
\hline pAg 5 & IgG ELISA & 111(Li) & nd & nd & 89 & nd & (Babba et al., 1994) \\
\hline pAg 5 & IgG ELISA & 122(Lu) & nd & nd & 78 & nd & (Babba et al., 1994) \\
\hline nAg5 & IgG ELISA & 58 & 40 & 36 & 100 & 70.2 & (Khabiri et al., 2006) \\
\hline nAg5 & IgG1 ELISA & 58 & 40 & 36 & 100 & 70.2 & (Khabiri et al., 2006) \\
\hline nAg5 & IgG4 ELISA & 58 & 40 & 36 & 75.8 & 93 & (Khabiri et al., 2006) \\
\hline nAg5 & IgE ELISA & 58 & 40 & 36 & 70 & 100 & (Khabiri et al., 2006) \\
\hline rAg5 & IgG ELISA & 34 & 18 & 36 & 65 & 89 & (Lorenzo et al., 2005b) \\
\hline rAg5-38 & IgG ELISA & 34 & 18 & 36 & 21 & 97 & (Lorenzo et al., 2005b) \\
\hline ЕpC1 & IgG WB & 324 & 70 & 500 & 88.7 & 95.6 & (Li et al., 2003b) \\
\hline $\mathrm{rEgcMDH}$ & IgG ELISA & 59 & 15 & 55 & 45 & 83 & (Lorenzo et al., 2005a) \\
\hline HSP20 & IgG1/4 WB & 95 & 37 & - & 64 & - & (Vacirca et al., 2011) \\
\hline Eg19 & IgG WB & 97 & 37 & 58 & 10 & 100 & (Delunardo et al., 2010) \\
\hline E14t & IgG ELISA & 102 & 95 & 68 & 35.3 & 91.7 & $\begin{array}{l}\text { (Hernandez-Gonzalez } \\
\text { et al., 2008) }\end{array}$ \\
\hline C317 & IgG ELISA & 102 & 95 & 68 & 58.8 & 80.9 & $\begin{array}{l}\text { (Hernandez-Gonzalez } \\
\text { et al., 2008) }\end{array}$ \\
\hline P5 & IgG WB & 60 & - & - & 97 & - & (Zhang et al., 2007) \\
\hline
\end{tabular}

* post-treatment. Abbreviations: Li - liver; Lu - lung; mAb-AP - affinity purified using monoclonal antibody; \# - coated with different buffer; pAg5 - purified antigen 5; nd - not determined.

Table 4. Features of assays for immunodiagnosis of cystic echinococcosis based on using native, recombinant and synthetic peptides of antigen 5 and other proteins

The fusion protein yielded an overall sensitivity of $92.2 \%$ and an overall specificity of $95.6 \%$. The combined levels of sensitivity and specificity achieved with the rEpC1-GST fusion protein for diagnosis of $\mathrm{CE}$ were exceptional, taking into account the large panel of serum samples that were tested ( $\mathrm{Li}$ et al., 2003b). The cDNA sequence coding for EpC1 has high amino acid sequence identity to a paralogue from Taenia solium, the cause of neurocysticercosis (NCC). To determine diagnostic antibody-binding regions on $\mathrm{EpC} 1$ recognized specifically by $\mathrm{CE}$ sera, 10 truncated regions (P1-10) of the immunogenic protein were expressed in Escherichia coli and subjected to immunoblotting (Zhang et al., 2007). One peptide, designated peptide 5 (P5, fused with glutathione-S-transferase (GST)) was positively recognized by sera from mice experimentally infected with oncospheres of E. granulosus and sera from surgically confirmed CE patients. Sera from NCC patients did not react with any of the peptides used. There are four amino acid substitutions in P5 compared with the T. solium sequence and these may form part of the epitope inducing CE-specific antibody. Ninety-seven per cent (58 of 60) of sera from confirmed CE patients recognized P5-GST.

By using ELISA, a cytosolic isoform of malate dehydrogenase (EgcMDH), an EF-hand calcium-binding protein (EgCaBP2), and a full-length (EgAFFPf) and a truncated form 
(EgAFFPt, aa 261 370) of actin yielded sensitivities between $58.6 \%$ and $89.7 \%$, and three of them were considered of complementary value (Virginio et al., 2003).

A purified alkaline phosphatase (EgAP) extracted from E. granulosus hydatid cyst membranes has shown exceptional diagnostic characteristics with $100 \%$ specificity without any decrease in sensitivity $(100 \%)$ with significant potential for use in routine diagnosis and follow-up of CE patients (Mahmoud and Abou Gamra, 2004). This mirrors the diagnostic value previously shown for purified alkaline phosphatase (pAP) from E. multilocularis metacestodes (Zhang et al., 2003a).

Purified recombinant thioredoxin peroxidase from E. granulosus (TPxEg) was used to screen sera from heavily infected mice and patients with confirmed hydatid infection ( $\mathrm{Li}$ et al., 2004). Only a portion of the sera reacted positively with the EgTPx-GST fusion protein in Western blots $(69.3 \%$ specificity and 39\% sensitivity with human sera), suggesting that EgTPx may form antibody-antigen complexes or that responses to the EgTPx antigen may be immunologically regulated.

IB revealed anti-HSP20 antibodies in a higher percentage of sera from patients with active disease than in sera from patients with inactive disease (Vacirca et al., 2011). A comparison of the ImmunoCAP system for testing serum IgE compared with IgG-ELISA and IgGWestern blotting revealed the former test had a higher specificity and lower cross-reactivity with a sensitivity of $73.6 \%$ (Marinova et al., 2011).

\subsection{Immunodiagnosis of alveolar echinococcosis in humans}

A number of advances in the serodiagnosis of $\mathrm{AE}$ have occurred in the past 10 years or so. These include identification of novel antigens, such as Em2 and Em18. Em2 was purified originally from E. multilocularis metacestode tissue extracts by affinity chromatography (Gottstein, 1985). Using AE sera to screen a cDNA library, a clone termed II/3 was cloned and showed very high performance for diagnosis (Vogel et al., 1988). A commerical kit based on Em2 and recombinant truncted protein II/3 so called Em2 Plus ELISA has shown high performance of AE diagnosis (Gottstein et al., 1993).

Em18, an 18-kD antigen from E. multilocularis, is highly specific for detection of AE (Ito et al., 2003a; Xiao et al., 2003). An ELISA system using the recombinant Em18 antigen (RecEm18) could differentially distinguish AE from CE (Ito et al., 2003a) and may be used for monitering surgical and/or chemotherapeutic treatment and the follow up of AE patients after treatment (Fujimoto et al., 2005). In order to compare the sequential responses of IgG subclasses to Em18 in sera from patients with AE, a total of 225 sera from 36 patients at different clinical stages according to the WHO-PNM staging system (Pawlowski et al., 2001) were tested. The levels of serum IgG and IgG4 against Em18 correlated with the PNM stages compared with sera from patients receiving no treatment (Tappe et al., 2010).

Antibody-screening was performed by (Reiter-Owona et al., 2009) using ELISA, IHA and IFAT, and confirmatory testing was done using the commercialized E. multilocularis-specific Em2plus-ELISA versus an in-house E. multilocularis-specific Em10-ELISA. The study showed that the Em2plus-ELISA reacted with 23.5\% CE-positive sera, whereas the Em10ELISA did not exhibit any cross-reactivity. In sera from patients with AE, confirmation by 
both ELISAs was achieved in $57.6 \%$ of cases, mostly in patients with an advanced stage of the disease and high antibody titers in the screening assays. False-negative reactions with both ELISAs occurred in 30.3\% cases, mostly in patients who had low antibody levels in the screening tests. The Em2plus-ELISA exhibited fewer false-negative reactions than the Em10ELISA. WB confirmed the positive results of both assays and was the assay with the highest reliability with different stages of $\mathrm{CE}$ and $\mathrm{AE}$, followed by the Em2plus-ELISA for AE. High antibody titres in the screening assays favour the detection of species-specific antibodies to either CE or AE (Reiter-Owona et al., 2009). The features of assays currently available for immunodiagnosis of alveolar echinococcosis using different antigens are presented in Table 5.

\begin{tabular}{cccccccc}
\hline \multirow{2}{*}{ Antigen } & \multirow{2}{*}{ TEST } & \multicolumn{3}{c}{ Number of subjects tested } & $\begin{array}{c}\text { Sensitivity } \\
(\%)\end{array}$ & $\begin{array}{c}\text { Specificity } \\
(\%)\end{array}$ & Reference \\
\cline { 3 - 5 } & & AE & Healthy & $\begin{array}{c}\text { Other } \\
\text { disease }\end{array}$ & & & \\
\hline Em2 & & & & & & \\
Em2 & IgG ELISA & 140 & 500 & 400 & 97.1 & 90.2 & (Gottstein et al., 1993) \\
IgG ELISA & 140 & 500 & 400 & 89.3 & 98.0 & (Gottstein et al., 1993) \\
Em2 & IgG ELISA & 47 & - & - & 81 & - & (Bart et al., 2007) \\
Em2 & IgG ELISA & 62 & - & 97 & 90 & 65 & (Muller et al., 2007) \\
rEm10 & IgG ELISA & 74 & 39 & 95 & 93.2 & 96.5 & (Helbig et al., 1993) \\
II/3-10 & IgG ELISA & 140 & 500 & 400 & 86.4 & 96.8 & (Gottstein et al., 1993) \\
CH-10 & IgG ELISA & 140 & 500 & 400 & 96 & $39-97$ & (Gottstein et al., 1993) \\
N3C & IgG ELISA & 140 & 500 & 400 & 96 & $18-94$ & (Gottstein et al., 1993) \\
pAP & IgG ELISA & 37 & 37 & 95 & 100 & 100 & (Ravinder et al., 1997) \\
Em70 & IgG ELISA & 39 & 32 & 115 & 100 & 99 & (Korkmaz et al., 2004) \\
Em90 & IgG ELISA & 39 & 32 & 115 & 100 & 99 & (Korkmaz et al., 2004) \\
II/3-10 & IgG ELISA & 62 & - & 97 & 79 & 92 & (Muller et al., 2007) \\
Em18 & IgG ELISA & 44 & 30 & 99 & 91 & 89.1 & (Jiang et al., 2001) \\
rEm13 & IgG ELISA & 28 & - & 72 & 82.1 & 100 & (Frosch et al., 1993) \\
rEm18 & IgG IB & 66 & 29 & 259 & 97 & 96.9 & (Ito et al., 1999) \\
rEm18 & IgG IB & 33 & 82 & 99 & 91 & 92.3 & (Jiang et al., 2001) \\
rEm18 & ELISA & 19 & 0 & 189 & 100 & 99 & (Xiao et al., 2003) \\
EmII & Dot-IB & 42 & - & - & 91.1 & - & (Feng et al., 2010) \\
\hline
\end{tabular}

Table 5. Features of assays for immunodiagnosis of alveolar echinococcosis using different antigens

Although AE serological diagnosis has made great strides to practical application, a recent expert consensus for alveolar echinococcosis diagnosis (Brunetti et al., 2010) stated that the most patients with $\mathrm{AE}$ are diagnosed at a later stage, which significantly impacts on quality of treatment. There is an urgent need for the early diagnosis. The application of new techniques is a way to address these issues; for example, recent microarray analysis identified 5 genes (Gapdh, Est1, Rlp3, Mdh-1, Rpl37) exhibiting a high level of congruency, and these may provide new diagnostic targets to predict disease status and progression (Gottstein et al., 2010).

\subsection{Circulating antigen detection}

Antibody detection is likely to indicate exposure to an Echinococcus infection, but it may not necessarily point to the presence of an established, viable infection, or the disease. Serum 
antibodies may persist for a prolonged period, reaching up to 10 years after hydatid cyst removal ( $\mathrm{Li}$ et al., 2004). In addition, the degree of antibody response may be related to the location and condition of a mature hydatid cyst. For instance, hydatid cysts in human lung, spleen, or kidney tend to be associated with lower serum antibody levels (Zhang and McManus, 2006). Furthermore, in Echinococcus-endemic villages, up to $26 \%$ or more of the general population may have antibodies to HCF antigens, but with only about $2 \%$ of the villagers having hydatid cysts (Craig et al., 1986; Chai et al., 1989; Gavidia et al., 2008), indicating that the antibody levels may not necessarily reflect the true prevalence of CE.

Antigen detection assays depend principally on the binding of specific polyclonal or monoclonal antibodies to parasite antigen present in serum or urine. A number of different assays have been developed to detect echinococcal antigens. The standard double antibody sandwich ELISA is a common method for measuring the presence and/or concentration of circulating parasite antigens. In the test, antibody raised to the targeted protein is coated onto a microtiter plate to capture antigen (Fig 3). The same antibody, that is enzyme labeled, is commonly used in the tertiary layer of the assay. This type of antigen capture therefore relies on the presence of multiple binding sites on the target antigens(s). Efforts to detect CAg in CE patients have been reviewed extensively by Craig (Craig et al., 1986).

CAg in serum is normally in the form of a circulating immune complex (CIC) with some in free form. Therefore, the serum needs to be treated with acid buffer or polyethylene glycol (PEG) to release and concentrate the circulating antigens. Acidic treatment $(0.2 \mathrm{M}$ glycine $/ \mathrm{HCl}$ ) of CE patient serum is quite straightforward to dissociate CIC (Craig et al., 1986). In a comparison of acid-treatment and PEG precipitation methods, all the sera of 30 confirmed positive cases of $\mathrm{CE}$ had detectable levels of antigen in the acid-treated sera (Craig, 1993). However, 23 (77\%) and 26 (87\%) sera of 30 confirmed cases had free antigen as well as CIC of an $8 \mathrm{kDa}$ antigen in the untreated and in the PEG precipitated sera, respectively. None of the sera from other patients with parasitic infections or viral hepatitis had any detectable levels of $8 \mathrm{kDa}$ antigen in the untreated, acid-treated or PEG-precipitated serum samples. These investigations, therefore, suggested that the demonstration of circulating antigen employing monospecific antibodies to affinity purified $8 \mathrm{kDa}$ antigen in acid-treated sera is more efficient than the detection of free circulating antigen or CIC in untreated or in PEG-precipitated sera (Kanwar et al., 1994).

IgM CICs tend to be positively associated with active hydatid disease (Craig et al., 1986; Matossian et al., 1992). Combining measurement of circulating antibody, CICs and CAg resulted in an increase from $77 \%$ to $90 \%$ compared to measurement of serum antibody alone (Moosa and Abdel-Hafez, 1994). Antigens in soluble CICs from CE patients have been characterized by separating them on SDS-PAGE (Craig et al., 1986) or by ion-exchange fast protein liquid chromatography (FPLC)(Bonifacino et al., 1993). Both studies indicated a candidate antigen detectable in serum with an approximate relative molecular mass of 60-67 $\mathrm{KDa}$, and which is also present in cyst fluid.

Comparison of CAg and IgG antibody using ELISA, together with Western blotting, showed a relatively low sensitivity (43\%) for detection of specific serum antigen in CE, compared to $75 \%$ for IgG antibodies (Craig, 1997). However, the specificity of this CAg ELISA was $90 \%$ when tested against sera from AE patients and 100\% against human cysticercosis sera. The limited 
cross-reactivity may be a way for practical diagnosis of $\mathrm{CE}$ in areas where $\mathrm{AE}$ and cysticercosis are co-endemic. The advantage of CAg detection is its high sensitivity for detecting CE in 54$57 \%$ of patients who are serum antibody negative (Moosa and Abdel-Hafez, 1994; Craig, 1997). CAg detection does appear, therefore, to be potentially useful as a secondary test for some suspected CE cases where antibody titers are low (Craig et al., 1986; Schantz, 1988).
A (1)
(2)
(3)
(4)
B (1)
(2)
(3)
(4)

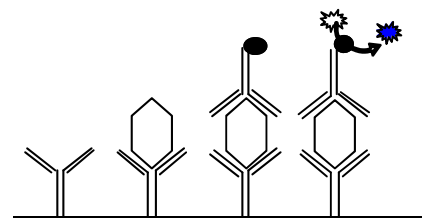
C (1) (2) (3) (4) (5)
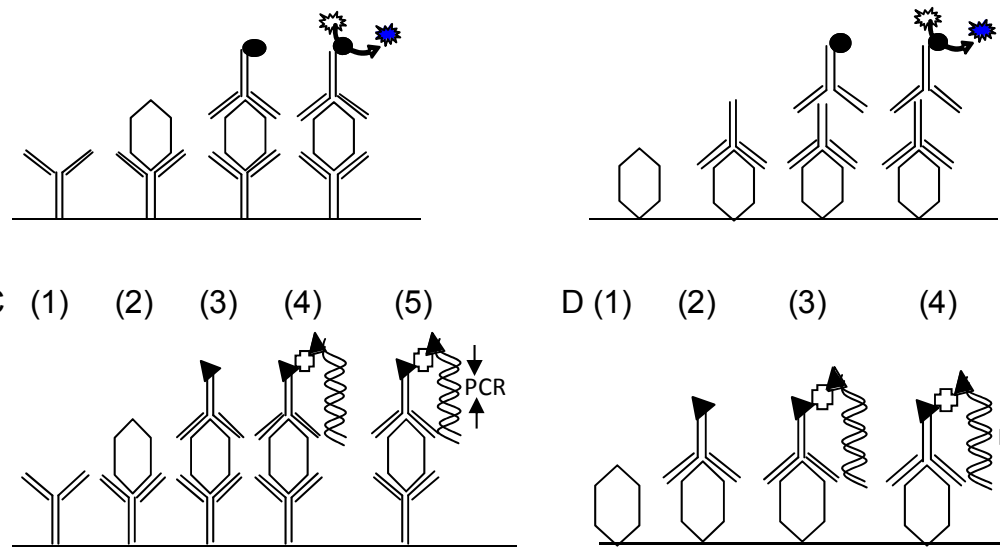
$\mathrm{D}(1) \quad(2) \quad(3) \quad(4)$

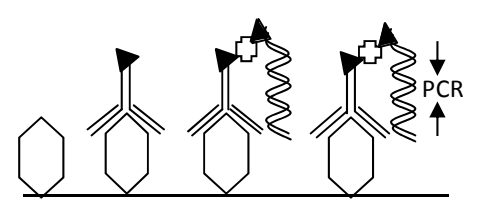
PFirst antibody $\bigcirc$ Test antigen $/$ Conjugate
Biotinylated antibody 凸Streptavidin

Fig. 3. Schematic of ELISA and immuno-PCR for detecting circulating antigen in serum. A. Sandwich ELISA. (1) Plate is coated with a capture antibody; (2) Serum sample is added, and any antigen present in the serum binds to the capture antibody; (3) Detecting antibody conjugate is added and binds to the antigen; (4) Substrate is added, and is converted by the enzyme to a detectable form. B. Direct ELISA. Plate is coated with diluted serum containing antigen; (2) Detecting antibody is added, and binds to antigen; (3) Enzyme-linked secondary antibody is added, and binds to detecting antibody; (4) Substrate is added, and is converted by the enzyme to a detectable form. C. Capture immuno-PCR. (1) Plate is coated with capture antibody; (2) Serum sample is added; (3) Biotinylated detecting antibody is added and binds to antigen; (4) Streptavidin and biotinylated reporter DNA are added, and the biotinylated antibody and biotinylated reporter DNA are linked by streptavidin; (5) Primers and PCR components are added and PCR or real- time PCR undertaken to quantify antigen. $\mathrm{D}$, Non-capture immuno-PCR. Serum sample is coated on the plate and the remainder of the steps are as for the capture-imuno-PCR (C).

A combination of CAg and antibody detection has been shown to increase the sensitivity from $85 \%$ (antibody only) to $89 \%$ (antibody+CAg) in ELISA of 115 surgically confirmed hydatid patients, 41 individuals exhibiting other parasitic and unrelated diseases, and 69 healthy subjects(Barbieri et al., 1994). 
Urinary hydatid antigen detection by co-agglutination (Co-A) potentially represents a costeffective and rapid test for diagnosis of $\mathrm{CE}$ in a rural or field setting. However, the lower sensitivity of Co-A for detection of antigen in the urine of a patient whose serum was positive for the antigen is possibly due to low levels of antigen in the urine (Ravinder et al., 2000).

Although there has been no application to date for echinococcal diagnosis, a technique for antigen detection, called immuno-polymerase chain reaction (immuno-PCR) (Fig $3 \mathrm{C}$ and D), has been developed (Sano et al., 1992). It combines the molecular recognition of antibodies with the high DNA amplification capability of PCR. The procedure is similar to conventional ELISA but is far more sensitive, and, in principle, could be applied for the detection of single antigen molecules. Instead of an enzyme, a DNA molecule is linked to the detection antibody and serves as a template for PCR (Fig 3). The DNA molecule is amplified and the PCR product is measured by gel electrophoresis. An improvement of this method is to amplify the DNA fragment by real-time PCR, thereby eliminating post-PCR analysis. Furthermore, real-time PCR is extremely accurate and sensitive, which should make it possible to quantitate very low amounts of DNA-coupled detection antibody with high accuracy.

\section{Immunodiagnosis of cystic echinococcosis in intermediate host animals}

Research towards developing serological tests for the diagnosis of larval cestode infection in animals has been largely unsuccessful. Substantial problems remain, due to the frequent existence of multiple infections with different taeniid species, antigenic cross-reactivity between these related parasites, and the low level of specific antibody response to infection. Problems with poor specificity and sensitivity of traditional serological tests for cysticercosis and hydatidosis have prevented the development of any practical test for ante-mortem diagnosis of infection. An approach to the diagnosis of Taenia infection by detecting circulating parasite antigen (Onyango-Abuje et al., 1996; Lightowlers, 1990; Harrison et al., 1989) offers some prospect for the development of a practical diagnostic test for cysticercosis.

In comparison with the extensive investigations in humans, relatively little research has been directed toward the development of immunodiagnostic techniques for E. granulosus infection in domesticated animals such as sheep and cattle. Currently, diagnosis of CE in intermediate hosts is based mainly on necropsy procedures. However, up to $37 \%$ of animals classified as positive at necropsy may be actually false positives caused by unspecific granulomas, pseudo-tuberculosis, fatty degeneration, abscesses, caseous lymphadenitis, and larval stage of Taenia hydatigena, whereas false negative diagnoses may be due to small intraparenchyma cysts (Larrieu et al., 2001; Gatti et al., 2007).

Accurate serological diagnosis of CE infection in livestock is necessary, but, as indicated above, difficult due to serological cross-reactions with several other species of taeniid cestodes including Taenia hydatigena and T.ovis (Lightowlers and Gottstein, 1995; Yong et al., 1984). Furthermore, natural intermediate host animals produce very poor antibody responses to infection compared with the relatively high levels of specific antibody seen in human infection (Lightowlers and Gottstein, 1995). In sheep, (Lightowlers et al., 1984) detected low levels of antibodies to AgB in the sera of some animals, whereas, others have 
reported reasonable high antibody responses to this molecule (Kanwar and Kanwar, 1994; Ibrahem et al., 1996). ELISA techniques using a variety of antigens have been applied to the immunodiagnosis of animal CE (Yong et al., 1984). In experimentally infected sheep, antibodies to hydatid antigens can be detected as early as 4-6 weeks post-infection (Yong et al., 1984). However, as referred to above, serological cross-reactions between E. granulosus and other cestodes limit the specific diagnosis of hydatid infection by ELISA using crude parasite antigens (Yong et al., 1984). Affinity purification of crude antigens with antibodies from animals immunized with homologous antigen (Craig and Rickard, 1982), or affinity depletion of cross-reactive antigens with monoclonal antibody (Craig et al., 1980), only partially reduces the cross-reactivity. Polysaccharide antigens from either the secretions produced during in vitro cultivation of E. granulosus PSC or from mouse hydatid cyst membranes by phenol extraction have been used to test sera from sheep (Ris et al., 1987). Although the antibody responses were significantly higher than those of sheep infected with $T$. hydatigena or $T$. ovis, very high cross-reacting antibody responses in the sera from $T$. hydatigena-infected animals were detected with the antigenic secretions from PSC. Neither antigen was sufficiently sensitive or specific for routine serodiagnostic use (Ris et al., 1987).

To develop an immunological method for the identification of sheep infected with $E$. granulosus, (Kittelberger et al., 2002) used an ELISA with antigen comprising either a purified 8 $\mathrm{kDa}$ hydatid cyst fluid protein (8kDaELISA), a recombinant EG95 oncosphere protein (OncELISA) or a crude protoscolex preparation (ProtELISA). Sera used for the assay validations were obtained from 249 sheep infected either naturally or experimentally with $E$. granulosus and from 1012 non-infected sheep. The highest diagnostic sensitivity was obtained using the ProtELISA at 62.7 and 51.4\%, depending on the cut-off. Assay sensitivities were lower for the 8kDaELISA and the OncELISA. Diagnostic specificities were high, ranging from 95.8 to $99.5 \%$, depending on the ELISA type and cut-off level chosen. A few sera from 39 sheep infected with T. hydatigena and from 19 sheep infected with T. ovis were recorded as positive. Western immunoblot analysis revealed that the dominant antigenic components in the crude protoscolex antigen preparation were macromolecules of about 70-150 kDa, most likely representing polysaccharides. This study demonstrated that the ProtELISA was the most effective immunological method of those assessed for detection of infection with E. granulosus in sheep. Because of its limited diagnostic sensitivity of about $50-60 \%$, it could be useful for the detection of the presence of infected sheep on a flock basis but cannot be used for reliable identification of individual animals infected with E. granulosus.

In a later study, Simsek and Koroglu (2004) investigated the antigenic characteristics of hydatid cyst fluid in sheep by SDS-PAGE to evaluate the sensitivity and specificity of HCFELISA and immunoblotting for diagnosis of sheep hydatidosis. One band with a molecular weight of $116 \mathrm{kDa}$ showed $88 \%$ sensitivity and $84 \%$ specificity in the immunoblot assay. Sensitivity $(60 \%)$ was less but specificity was higher $(94 \%)$ with the HCF-ELISA (Simsek and Koroglu, 2004). Ghorbanpoor et al. (2006) were able to detect specific circulating antigens or antibodies in the serum and urine of 13 experimentally infected sheep.

\section{DNA techniques}

In addition to imaging and serological tests, identification of Echinococcus infection via PCRbased assays and DNA sequencing using tissue biopsy from the patients can be of choice for 
confirming diagnosis of echinococcosis for these unconfirmed and complicated cases. DNA techniques are now available that allow the unambiguosus identification of Echinococcus species and E. granulosus strains using metacestode material excised from intermediate and human hosts provide a major new approach to the diagnosis of echinococcosis (Yang et al., 2006; McManus, 2006; McManus and Thompson, 2003; Thompson and McManus, 2001). Detection or amplification of E. multilocularis nucleic acids in clinical samples has been used in diagnosis of AE infections in patients (Myjak et al., 2003).

\section{The challenges and future directions}

Almost all available immunodiagnostic techniques, including methods for detecting specific antibodies and circulating parasite antigens in serum or other body fluids, have been applied for diagnosing echinococcosis. However, all the tools developed to date, are generally applicable for laboratory research purposes only. None of the available diagnostic tools, kits or methods are generally accepted by clinical physicians. Nevertheless, such serological tools are potentially important for epidemiological studies, confirmation of infection status and the treatment and the monitoring of control programs and efforts should continue so that new assays for improved, practical diagnosis of echinococcosis are developed.

\section{Conclusion}

This Chapter provides an update of recent progress in research on the immunology and serological diagnosis of echinococcosis caused by E. granulosus and E. multilocularis. Cystic echinococcosus (CE) is characterized by long term growth of larval cysts in humans and other intermediate hosts, whereas, alveolar echincoccosis is defined by its chronic progression in human liver, resulting in high mortality. Although the host-parasite interplay, in most cases of $\mathrm{AE}$ and $\mathrm{CE}$, appears to be harmonious and clinically asymptomatic for a long period after infection, the host does produce detectable humoral and cellular responses against the causative parasites. Antibody responses against early $E$. granulosus infection are weak being, usually, undetectable in the early two to three weeks following infection. During the establishment stage, the parasite produces significant quantities of antigens that modulate the immune response including antibody production, which is essential for serodiagnostic measurement.

It is clear that the improvement of immunodiagnostic methods for echinococcosis has greatly contributed to a better understanding of the prevalence and the epidemiology of the infection. Immunodiagnostic tests will also provide a valuable tool in measuring the impact of the disease on human health and on animal production, data that are still missing in most endemic areas. The assays may contribute to the diagnosis of $\mathrm{CE}$ and $\mathrm{AE}$ and the follow-up of treatment. Ultrasound and X-ray imaging methods are generally inaccessible and/or too expensive for the rural population at risk. Under these conditions, serology may provide the only tool for diagnosis of the infection. Finally, efforts should continue to provide cheap, reliable and standardised serodiagnostic methods more widely available for both AE and CE.

\section{Acknowledgements}

Echinococcosis research projects by the authors are supported by the National Natural Science Foundation of China (30760185 for WBZ, 30960342 and 81160201 for HW) and China 
Special Research Projects for Public Sectors (Agriculture), and the Australian National Health and Medical Research Council.

\section{References}

Abdi, J., Kazemi, B., Mohebali, M., Bandehpour, M., Rahimi, M. T. \&Rokni, M. B. (2010). Gene cloning, expression and serological evaluation of the $12-\mathrm{kDa}$ antigen-B subunit from Echinococcus granulosus. Ann Trop Med Parasitol, Vol.104, No.5, pp. 399-407, ISSN: 1364-8594

Afferni, C., Pini, C., Misiti-Dorello, P., Bernardini, L., Conchedda, M. \&Vicari, G. (1984). Detection of specific IgE antibodies in sera from patients with hydatidosis. Clin Exp Immunol, Vol.55, No.3, pp.587-592, ISSN:1356-2249, ISSN: 1474-1741

Al-Sherbiny, M. M., Farrag, A. A., Fayad, M. H., Makled, M. K., Tawfeek, G. M. \&Ali, N. M. (2004). Application and assessment of a dipstick assay in the diagnosis of hydatidosis and trichinosis. Parasitol Res, Vol. 93, No.2, pp. 87-95, ISSN:0932-0113

Allen, J. E. \&Maizels, R. M. (2011). Diversity and dialogue in immunity to helminths. Nat Rev Immunol, Vol.11, No.6, pp.375-388, ISSN: 1474-1741

Altintas, N. (2003). Past to present: echinococcosis in Turkey. Acta Trop, Vol.85, No.2, pp. 105-112, ISSN: 0001-706X

Arend, A. C., Zaha, A., Ayala, F. J. \&Haag, K. L. (2004). The Echinococcus granulosus antigen B shows a high degree of genetic variability. Exp Parasitol. Vol.108, No.1-2, pp. 7680, ISSN: 0014-4894

Babba, H., Messedi, A., Masmoudi, S., Zribi, M., Grillot, R., Ambriose-Thomas, P., Beyrouti, I. \&Sahnoun, Y. (1994). Diagnosis of human hydatidosis: comparison between imagery and six serologic techniques. Am J Trop Med Hyg, Vol.50, No.1, pp. 64-68, ISSN: 0002-9637

Barbieri, M., Fernandez, V., Gonzalez, G., Luaces, V. M. \&Nieto, A. (1998). Diagnostic evaluation of a synthetic peptide derived from a novel antigen B subunit as related to other available peptides and native antigens used for serology of cystic hydatidosis. Parasite Immunol, Vol.20, No.2, pp. 51-61, ISSN: 1365-3024

Barbieri, M., Severi, M. A., Pirez, M. I., Battistoni, J. \&Nieto, A. (1994). Use of specific antibody and circulating antigen serum levels in the hydatid immunodiagnosis of asymptomatic population. Int J Parasitol, Vol. 24, No.7, pp. 937-942, ISSN: 0020-7519

Barbieri, M., Sterla, S., Battistoni, J. \&Nieto, A. (1993). High performance latex reagent for hydatid serology using an Echinococcus granulosus lipoprotein antigen fraction purified from cyst fluid in one step. Int J Parasitol, Vol.23, No.5, pp.565-572, ISSN: 0020-7519

Bart, J. M., Piarroux, M., Sako, Y., Grenouillet, F., Bresson-Hadni, S., Piarroux, R. \&Ito, A. (2007). Comparison of several commercial serologic kits and Em18 serology for detection of human alveolar echinococcosis. Diagn Microbiol Infect Dis, Vol.59, No.1, pp. 93-95, ISSN: 0732-8893

Bauder, B., Auer, H., Schilcher, F., Gabler, C., Romig, T., Bilger, B. \&Aspock, H. (1999). Experimental investigations on the $\mathrm{B}$ and $\mathrm{T}$ cell immune response in primary alveolar echinococcosis. Parasite Immunol, Vol.21, No.8, pp. 409-421, ISSN: 13653024

Bayraktar, M. R., Mehmet, N. \&Durmaz, R. (2005). Th1 and Th2 inducing cytokines in Cystic echinococcosis. Turkiye Parazitol Derg, Vol.29, No.3, pp.167-170. 
Baz, A., Carol, H., Fernandez, V., Mourglia-Ettlin, G., Nieto, A., Orn, A. \&Dematteis, S. (2008). Echinococcus granulosus: induction of T-independent antibody response against protoscolex glycoconjugates in early experimental infection. Exp Parasitol, Vol.119, No.4, pp. 460-466, ISSN: 0014-4894

Baz, A., Ettlin, G. M. \&Dematteis, S. (2006). Complexity and function of cytokine responses in experimental infection by Echinococcus granulosus. Immunobiology, Vol.211, No.12, pp. 3-9, ISSN: 0171-2985

Ben Nouir, N., Nunez, S., Gianinazzi, C., Gorcii, M., Muller, N., Nouri, A., Babba, H. \&Gottstein, B. (2008). Assessment of Echinococcus granulosus somatic protoscolex antigens for serological follow-up of young patients surgically treated for cystic echinococcosis. J Clin Microbiol, Vol.46, No.5, pp. 1631-1640, ISSN: 1098-660X

Bonifacino, R., Craig, P., Carter, S., Malgor, R. \&Dixon, J. (1993). Partial characterization of antigens in circulating immune complexes in cystic hydatid patients treated with albendazole. Trans R Soc Trop Med Hyg, Vol. 87, No.1, pp. 97-102, ISSN: 0035-9203

Bresson-Hadni, S., Liance, M., Meyer, J. P., Houin, R., Bresson, J. L. \&Vuitton, D. A. (1990). Cellular immunity in experimental Echinococcus multilocularis infection. II. Sequential and comparative phenotypic study of the periparasitic mononuclear cells in resistant and sensitive mice. Clin Exp Immunol, Vol.82, No.2, pp. 378-383, ISSN: 1474-1741

Brunetti, E., Kern, P. \&Vuitton, D. A. (2010). Expert consensus for the diagnosis and treatment of cystic and alveolar echinococcosis in humans. Acta Trop, Vol.114, No.1, pp. 1-16, ISSN: 0001-706X

Budke, C. M. (2006). Global socioeconomic impact of cystic echinococcosis. Emerg Infect Dis, Vol.12, No.2), pp. 296-303, ISSN: 1080-6040

Cabrera, P. A., Irabedra, P., Orlando, D., Rista, L., Haran, G., Vinals, G., Blanco, M. T., Alvarez, M., Elola, S., Morosoli, D., Morana, A., Bondad, M., Sambran, Y., Heinzen, T., Chans, L., Pineyro, L., Perez, D. \&Pereyra, I. (2003). National prevalence of larval echinococcosis in sheep in slaughtering plants Ovis aries as an indicator in control programmes in Uruguay. Acta Trop, Vol.85, No.2, pp. 281-285, ISSN: 0001706X

Chai, J., Sultan, Y. \&Wei, M. (1989). An investigation on the epidemiologic baseline of hydatid disease in Xinjiang, China. I. A sero-epidemiological survey of human hydatidosis. Endemic Disease Bulletin (in Chinese), Vol.4, pp. 1-8, ISSN: 1000-3711

Chamekh, M., Gras-Masse, H., Bossus, M., Facon, B., Dissous, C., Tartar, A. \&Capron, A. (1992). Diagnostic value of a synthetic peptide derived from Echinococcus granulosus recombinant protein. J Clin Invest, Vol.89, No.2, pp. 458-464, ISSN: 0021-9738

Chemale, G., Ferreira, H. B., Barrett, J., Brophy, P. M. \&Zaha, A. (2005). Echinococcus granulosus antigen B hydrophobic ligand binding properties. Biochim Biophys Acta, Vol.1747, No.2, pp.189-194, ISSN: 0006-3002

Chemale, G., Haag, K. L., Ferreira, H. B. \&Zaha, A. (2001). Echinococcus granulosus antigen B is encoded by a gene family. Mol Biochem Parasitol, Vol.116, No.2, pp. 233-237, ISSN: 0166-6851

Chi, P. S., Fan, Y. L., Zhang, W. B., Zhang, Z. Z., Alili, H. \&Zhang, Y. L. (1989). The epidemic situations of cystic echinococcosis in China. Xinjiang Agricultural Sciences 1989, Vol.3, pp. 35-38(in Chinese), ISSN: 1001-4330 
Clutterbuck, E. J., Hirst, E. M. \&Sanderson, C. J. (1989). Human interleukin-5 (IL-5) regulates the production of eosinophils in human bone marrow cultures: comparison and interaction with IL-1, IL-3, IL-6, and GMCSF. Blood, Vol.73, No.6, pp.1504-1512, ISSN: 0006-4971

Collaboration, groups, in \&China (2005). A national survey on current status of the important parasitic diseases in human population. Zhongguo Ji Sheng Chong Xue $Y u$ Ji Sheng Chong Bing Za Zhi, Vol.23, pp. 332-340, ISSN: 1000-7423

Craig, P. (1997). Immunodiagnosis of Echinococcus granulosus and comparison of techniques for diagnosis of canine echinococcosis. In: Compendium on echinococcosis in Africa and Middle Eastern counties with special reference to Morocco, F.L. Andersen, J.J. Chai, F.J. Liu (Eds.), 85-118, Provo, Utah: Brigham Young University,

Craig, P. S. (1986). Detection of specific circulating antigen, immune complexes and antibodies in human hydatidosis from Turkana (Kenya) and Great Britain, by enzyme-immunoassay. Parasite Immunol, Vol. 8, No.2, pp. 171-188, ISSN: 1365-3024

Craig, P. S. (1993). Immunodiagnosis of Echinococcus granulosus. Provo, Utah: Brigham Young University.

Craig, P. S. \&Larrieu, E. (2006). Control of cystic echinococcosis/hydatidosis: 1863-2002. Adv Parasitol, Vol.61, pp. 443-508, ISSN: 0065-308X

Craig, P. S., McManus, D. P., Lightowlers, M. W., Chabalgoity, J. A., Garcia, H. H., Gavidia, C. M., Gilman, R. H., Gonzalez, A. E., Lorca, M., Naquira, C., Nieto, A. \&Schantz, P. M. (2007). Prevention and control of cystic echinococcosis. Lancet Infect Dis, Vol.7, No.6, pp. 385-394, ISSN: 1473-3099

Craig, P. S., Mitchell, G. F., Cruise, K. M. \&Rickard, M. D. (1980). Hybridoma antibody immunoassays for the detection of parasitic infection: attempts to produce an immunodiagnostic reagent for a larval taeniid cestode infection. Aust J Exp Biol Med Sci, Vol.58, No.4, pp. 339-350, ISSN: 0004-945X

Craig, P. S. \&Nelson, G. S. (1984). The detection of circulating antigen in human hydatid disease. Ann Trop Med Parasitol, Vol.78, No.3, pp. 219-227, ISSN: 1364-8594

Craig, P. S. \&Rickard, M. D. (1982). Antibody responses of experimentally infected lambs to antigens collected during in vitro maintenance of the adult, metacestode or oncosphere stages of Taenia hydatigena and Taenia ovis with further observations on anti-oncospheral antibodies. Z Parasitenkd, Vol.67, No.2, pp. 197-209, ISSN: 00443255

Craig, P. S., Zeyhle, E. \&Romig, T. (1986). Hydatid disease: research and control in Turkana. II. The role of immunological techniques for the diagnosis of hydatid disease. Trans R Soc Trop Med Hyg, Vol.80, No.2, pp. 183-192, ISSN: 0035-9203

Daeki, A. O., Craig, P. S. \&Shambesh, M. K. (2000). IgG-subclass antibody responses and the natural history of hepatic cystic echinococcosis in asymptomatic patients. Ann Trop Med Parasitol, Vol.94, No.4, pp. 319-328, ISSN: 1364-8594

Dai, W. J., Hemphill, A., Waldvogel, A., Ingold, K., Deplazes, P., Mossmann, H. \&Gottstein, B. (2001). Major carbohydrate antigen of Echinococcus multilocularis induces an immunoglobulin $\mathrm{G}$ response independent of alphabeta+ CD4+ $\mathrm{T}$ cells. Infect Immun, Vol.69, No.10, pp. 6074-6083, ISSN: 0019-9567

de la Rue, M. L., Yamano, K., Almeida, C. E., Iesbich, M. P., Fernandes, C. D., Goto, A., Kouguchi, H. \&Takahashi, K. (2010). Serological reactivity of patients with 
Echinococcus infections (E. granulosus, E. vogeli, and E. multilocularis) against three antigen B subunits. Parasitol Res, Vol.106, No.3, pp. 741-745, ISSN:0932-0113

Delunardo, F., Ortona, E., Margutti, P., Perdicchio, M., Vacirca, D., Teggi, A., Sorice, M. \&Siracusano, A. (2010). Identification of a novel $19 \mathrm{kDa}$ Echinococcus granulosus antigen. Acta Trop, Vol.113, No.1, pp.42-47, ISSN: 0001-706X

Deplazes, P. (2006). Ecology and epidemiology of Echinococcus multilocularis in Europe. Parassitologia, Vol.48, No.1-2, pp. 37-39, ISSN: 0048-2951

Dessaint, J. P., Bout, D., Wattre, P. \&Capron, A. (1975). Quantitative determination of specific IgE antibodies to Echinococcus granulosus and IgE levels in sera from patients with hydatid disease. Immunology, Vol.29, No.5, pp. 813-823, ISSN: 13652567

Dvoroznakova, E., Hrckova, G., Boroskova, Z., Velebny, S. \&Dubinsky, P. (2004). Effect of treatment with free and liposomized albendazole on selected immunological parameters and cyst growth in mice infected with Echinococcus multilocularis. Parasitol Int, Vol.53, No.4, pp. 315-325, ISSN: 1383-5769

Eckert, J., Conraths, F. J. \&Tackmann, K. (2000). Echinococcosis: an emerging or re-emerging zoonosis? Int J Parasitol, Vol.30, No.12-13, pp. 1283-1294, ISSN: 0020-7519

Emery, I., Liance, M. \&Leclerc, C. (1997). Secondary Echinococcus multilocularis infection in A/J mice: delayed metacestode development is associated with Th1 cytokine production. Parasite Immunol, Vol.19, No.11, pp. 493-503, ISSN: 1365-3024

Feng, X., Wen, H., Zhang, Z., Chen, X., Ma, X., Zhang, J., Qi, X., Bradshaw, H., Vuitton, D. \&Craig, P. S. (2010). Dot immunogold filtration assay (DIGFA) with multiple native antigens for rapid serodiagnosis of human cystic and alveolar echinococcosis. Acta Trop, Vol.113, No.2, pp. 114-120, ISSN: 1873-6254

Fernandez, V., Ferreira, H. B., Fernandez, C., Zaha, A. \&Nieto, A. (1996). Molecular characterisation of a novel 8-kDa subunit of Echinococcus granulosus antigen B. Mol Biochem Parasitol, Vol.77, No.2, pp. 247-250, ISSN: 0166-6851

Force, L., Torres, J. M., Carrillo, A. \&Busca, J. (1992). Evaluation of eight serological tests in the diagnosis of human echinococcosis and follow-up. Clin Infect Dis, Vol.15, No.3, pp. 473-480, ISSN: 1537-6591

Frosch, P. M., Geier, C., Kaup, F. J., Muller, A. \&Frosch, M. (1993). Molecular cloning of an echinococcal microtrichal antigen immunoreactive in Echinococcus multilocularis disease. Mol Biochem Parasitol, Vol. 58, No.2, pp. 301-310, ISSN: 0166-6851

Fujimoto, Y., Ito, A., Ishikawa, Y., Inoue, M., Suzuki, Y., Ohhira, M., Ohtake, T. \&Kohgo, Y. (2005). Usefulness of recombinant Em18-ELISA to evaluate efficacy of treatment in patients with alveolar echinococcosis. J Gastroenterol, Vol.40, No.4, pp. 426-431, ISSN: $1435-5922$

Gatti, A., Alvarez, A. R., Araya, D., Mancini, S., Herrero, E., Santillan, G. \&Larrieu, E. (2007). Ovine echinococcosis I. Immunological diagnosis by enzyme immunoassay. Vet Parasitol, Vol.143, No.2, pp. 112-121, ISSN: 0304-4017

Gavidia, C. M., Gonzalez, A. E., Zhang, W., McManus, D. P., Lopera, L., Ninaquispe, B., Garcia, H. H., Rodriguez, S., Verastegui, M., Calderon, C., Pan, W. K. \&Gilman, R. H. (2008). Diagnosis of cystic echinococcosis, central Peruvian Highlands. Emerg Infect Dis, Vol.14, No.2, pp. 260-266, ISSN: 1080-6040

Ghorbanpoor, M., Razi Jalali, M. H., Hoghooghi Rad, N., Nabavi, L., Esmail Zadeh, S., Rafiei, A. \&Haji Hajikolaei, M. R. (2006). Detection of specific hydatid antigens and 
antibodies in serum and urine of experimentally infected sheep. Vet Parasitol, Vol.142, No.1-2, pp. 91-94 ISSN: 0304-4017

Godot, V., Harraga, S., Beurton, I., Deschaseaux, M., Sarciron, E., Gottstein, B. \&Vuitton, D. A. (2000). Resistance/susceptibility to Echinococcus multilocularis infection and cytokine profile in humans. I. Comparison of patients with progressive and abortive lesions. Clin Exp Immunol, Vol.121, No.3, pp. 484-490, ISSN: 1474-1741

Gonzalez-Sapienza, G., Lorenzo, C. \&Nieto, A. (2000). Improved immunodiagnosis of cystic hydatid disease by using a synthetic peptide with higher diagnostic value than that of its parent protein, Echinococcus granulosus antigen B. J Clin Microbiol, Vol.38, No.11, pp. 3979-3983, ISSN: 1098-660X

Gonzalez, G., Spinelli, P., Lorenzo, C., Hellman, U., Nieto, A., Willis, A. \&Salinas, G. (2000). Molecular characterization of P-29, a metacestode-specific component of Echinococcus granulosus which is immunologically related to, but distinct from, antigen 5. Mol Biochem Parasitol, Vol.105, No.2), pp. 177-184, ISSN: 0166-6851

Gottstein, B. (1984). An immunoassay for the detection of circulating antigens in human echinococcosis. Am J Trop Med Hyg, Vol.33, No.6, pp. 1185-1191, ISSN: 0002-9637

Gottstein, B. (1985). Purification and characterization of a specific antigen from Echinococcus multilocularis. Parasite Immunol, Vol.7, No.3, pp. 201-212, ISSN: 1365-3024

Gottstein, B., Dai, W. J., Walker, M., Stettler, M., Muller, N. \&Hemphill, A. (2002). An intact laminated layer is important for the establishment of secondary Echinococcus multilocularis infection. Parasitol Res, Vol.88, No.9, pp. 822-828, ISSN:0932-0113

Gottstein, B. \&Felleisen, R. (1995). Protective immune mechanisms against the metacestode of Echinococcus multilocularis. Parasitol Today, Vol.11, No.9, pp. 320-326, ISSN: 01694758

Gottstein, B., Jacquier, P., Bresson-Hadni, S. \&Eckert, J. (1993). Improved primary immunodiagnosis of alveolar echinococcosis in humans by an enzyme-linked immunosorbent assay using the Em2plus antigen. J Clin Microbiol, Vol.31, No.2, pp. 373-376, ISSN: 1098-660X

Gottstein, B., Wittwer, M., Schild, M., Merli, M., Leib, S. L., Muller, N., Muller, J. \&Jaggi, R. (2010). Hepatic gene expression profile in mice perorally infected with Echinococcus multilocularis eggs. PLoS One, Vol.5, No.4, pp. e9779, ISSN: 1932-6203

Haag, K. L., Gottstein, B., Muller, N., Schnorr, A. \&Ayala, F. J. (2006). Redundancy and recombination in the Echinococcus $\mathrm{AgB}$ multigene family: is there any similarity with protozoan contingency genes? Parasitology, Vol.133, (Pt. 4), pp.411-419, ISSN: 0031-1820

Harraga, S., Godot, V., Bresson-Hadni, S., Mantion, G. \&Vuitton, D. A. (2003). Profile of cytokine production within the periparasitic granuloma in human alveolar echinococcosis. Acta Trop, Vol85, No.2, pp. 231-236, ISSN: 0001-706X

Harrison, L. J., Joshua, G. W., Wright, S. H. \&Parkhouse, R. M. (1989). Specific detection of circulating surface/secreted glycoproteins of viable cysticerci in Taenia saginata cysticercosis. Parasite Immunol, Vol.11, No.4, pp. 351-370, ISSN: 1365-3024

Hegglin, D., Bontadina, F., Gloor, S., Romig, T., Deplazes, P. \&Kern, P. (2008). Survey of public knowledge about Echinococcus multilocularis in four European countries: need for proactive information. BMC Public Health Vol. 8: 247-257, ISSN:1471-2458 
Helbig, M., Frosch, P., Kern, P. \&Frosch, M. (1993). Serological differentiation between cystic and alveolar echinococcosis by use of recombinant larval antigens. J Clin Microbiol, Vol.31, No.12, pp. 3211-3215, ISSN: 1098-660X

Hernandez-Gonzalez, A., Muro, A., Barrera, I., Ramos, G., Orduna, A. \& Siles-Lucas, M. (2008). Usefulness of four different Echinococcus granulosus recombinant antigens for serodiagnosis of unilocular hydatid disease (UHD) and postsurgical follow-up of patients treated for UHD. Clin Vaccine Immunol, Vol.15, No.1, pp. 147-153, ISSN: 1556-679X

Ibrahem, M. M., Craig, P. S., McVie, A., Ersfeld, K. \&Rogan, M. T. (1996). Echinococcus granulosus antigen B and seroreactivity in natural ovine hydatidosis. Res Vet Sci, Vol.61, No.2, pp. 102-106, ISSN: 0034-5288

Irabuena, O., Nieto, A., Ferreira, A. M., Battistoni, J. \&Ferragut, G. (2000). Characterization and optimization of bovine Echinococcus granulosus cyst fluid to be used in immunodiagnosis of hydatid disease by ELISA. Rev Inst Med Trop Sao Paulo, Vol.42, No.5, pp. 255-262, ISSN 0036-4665

Ito, A., Ma, L., Schantz, P. M., Gottstein, B., Liu, Y. H., Chai, J. J., Abdel-Hafez, S. K., Altintas, N., Joshi, D. D., Lightowlers, M. W. \&Pawlowski, Z. S. (1999). Differential serodiagnosis for cystic and alveolar echinococcosis using fractions of Echinococcus granulosus cyst fluid (antigen B) and E. multilocularis protoscolex (EM18). Am J Trop Med Hyg, Vol.60, No.2, pp. 188-192, ISSN: 0002-9637

Ito, A., Sako, Y., Yamasaki, H., Mamuti, W., Nakaya, K., Nakao, M. \&Ishikawa, Y. (2003a). Development of Em18-immunoblot and Em18-ELISA for specific diagnosis of alveolar echinococcosis. Acta Trop, Vol.85, No.2, pp. 173-182, ISSN: 0001-706X

Ito, A., Urbani, C., Jiamin, Q., Vuitton, D. A., Dongchuan, Q., Heath, D. D., Craig, P. S., Zheng, F. \&Schantz, P. M. (2003b). Control of echinococcosis and cysticercosis: a public health challenge to international cooperation in China. Acta Trop, Vol.86, No.1, pp. 3-17, ISSN: 0001-706X

Jiang, L., Wen, H. \&Ito, A. (2001). Immunodiagnostic differentiation of alveolar and cystic echinococcosis using ELISA test with 18-kDa antigen extracted from Echinococcus protoscoleces. Trans R Soc Trop Med Hyg, Vol.95, No.3, pp. 285-288, ISSN: 0035-9203

Kalantari, E., Bandehpour, M., Pazoki, R., Taghipoor-Lailabadi, N., Khazan, H., Mosaffa, N., Nazaripouya, M. R. \&Kazemi, B. (2010). Application of recombinant Echinococcus granulosus antigen B to ELISA kits for diagnosing hydatidosis. Parasitol Res, Vol.106, No.4, pp. 847-851, ISSN:0932-0113

Kamenetzky, L., Muzulin, P. M., Gutierrez, A. M., Angel, S. O., Zaha, A., Guarnera, E. A. \&Rosenzvit, M. C. (2005). High polymorphism in genes encoding antigen B from human infecting strains of Echinococcus granulosus. Parasitology, Vol.131, (Pt 6), pp.805-815, ISSN: 0031-1820

Kanan, J. H. \&Chain, B. M. (2006). Modulation of dendritic cell differentiation and cytokine secretion by the hydatid cyst fluid of Echinococcus granulosus. Immunology, Vol.118, No.2), pp. 271-278, ISSN: 1365-2567

Kanwar, J. R. \&Kanwar, R. (1994). Purification and partial immunochemical characterization of a low molecular mass, diagnostic Echinococcus granulosus immunogen for sheep hydatidosis. FEMS Immunol Med Microbiol, Vol.9, No.2, pp. 101-107, ISSN: 09288244 
Kanwar, J. R., Kanwar, R. K., Grewal, A. S. \&Vinayak, V. K. (1994). Significance of detection of immune-complexed $8 \mathrm{kDa}$ hydatid-specific antigen for immunodiagnosis of hydatidosis. FEMS Immunol Med Microbiol, Vol.9, No.3, pp. 231-236, ISSN: 09288244

Khabiri, A. R., Bagheri, F., Assmar, M. \&Siavashi, M. R. (2006). Analysis of specific IgE and IgG subclass antibodies for diagnosis of Echinococcus granulosus. Parasite Immunol, Vol.28, No.8, pp. 357-362, ISSN: 1365-3024

King, C. L. \&Nutman, T. B. (1993). IgE and IgG subclass regulation by IL-4 and IFN-gamma in human helminth infections. Assessment by B cell precursor frequencies. J Immunol, Vol.151, No.1, pp. 458-465, ISSN: 1550-6606

Kittelberger, R., Reichel, M. P., Jenner, J., Heath, D. D., Lightowlers, M. W., Moro, P., Ibrahem, M. M., Craig, P. S. \&O'Keefe, J. S. (2002). Evaluation of three enzymelinked immunosorbent assays (ELISAs) for the detection of serum antibodies in sheep infected with Echinococcus granulosus. Vet Parasitol, Vol.110, No.1-2, pp. 57-76, ISSN: 0304-4017

Kocherscheidt, L., Flakowski, A. K., Gruner, B., Hamm, D. M., Dietz, K., Kern, P. \&Soboslay, P. T. (2008). Echinococcus multilocularis: inflammatory and regulatory chemokine responses in patients with progressive, stable and cured alveolar echinococcosis. Exp Parasitol, Vol.119, No.4, pp. 467-474, ISSN: 0014-4894

Korkmaz, M., Inceboz, T., Celebi, F., Babaoglu, A. \&Uner, A. (2004). Use of two sensitive and specific immunoblot markers, em70 and em90, for diagnosis of alveolar echinococcosis. J Clin Microbiol, Vol.42, No.7, pp. 3350-3352, ISSN: 1098-660X

Larrieu, E., Costa, M. T., Cantoni, G., Alvarez, R., Cavagion, L., Labanchi, J. L., Bigatti, R., Araya, D., Herrero, E., Alvarez, E., Mancini, S. \&Cabrera, P. (2001). Ovine Echinococcus granulosus transmission dynamics in the province of Rio Negro, Argentina, 1980-1999. Vet Parasitol, Vol.98, No.4, pp. 263-272, ISSN: 0304-4017

Leggatt, G. R. \&McManus, D. P. (1994). Identification and diagnostic value of a major antibody epitope on the $12 \mathrm{kDa}$ antigen from Echinococcus granulosus (hydatid disease) cyst fluid. Parasite Immunol, Vol.16, No.2, pp. 87-96, ISSN: 1365-3024

Li, F. R., Shi, Y. E., Shi, D. Z., Vuitton, D. A. \&Craig, P. S. (2003a). [Kinetic analysis of cytokines and immunoglobulin $G$ subclass in BALB/c mice infected with Echinococcus alveolaris]. Zhongguo Ji Sheng Chong Xue Yu Ji Sheng Chong Bing Za Zhi, Vol.21, No.6, pp.357-360, ISSN: 1000-7423

Li, J., Zhang, W. B. \&McManus, D. P. (2004). Recombinant antigens for immunodiagnosis of cystic echinococcosis. Biol Proced Online, Vol.6, pp. 67-77,

Li, J., Zhang, W. B., Wilson, M., Ito, A. \&McManus, D. P. (2003b). A novel recombinant antigen for immunodiagnosis of human cystic echinococcosis. Journal of infectious diseases, Vol.188, No.12, pp. 1952-1961,

Li, T., Ito, A., Chen, X., Sako, Y., Qiu, J., Xiao, N., Qiu, D., Nakao, M., Yanagida, T. \&Craig, P. S. (2010). Specific IgG responses to recombinant antigen B and em18 in cystic and alveolar echinococcosis in china. Clin Vaccine Immunol, Vol.17, No.3, pp. 470-475,

Li, T. Y., Qiu, J. M., Yang, W., Craig, P. S., Chen, X. W., Xiao, N., Ito, A., Giraudoux, P., Mamuti, W., Yu, W. \&Schantz, P. M. (2005). Echinococcosis in Tibetan populations, western Sichuan Province, China. Emerg Infect Dis, Vol.11, No.12, pp. 1866-1873, ISSN: 1080-6040 
Lightowlers, M. W. (1990). Cestode infections in animals: immunological diagnosis and vaccination. Rev Sci Tech, Vol.9, No.2, pp. 463-487,

Lightowlers, M. W. \&Gottstein, B. (1995). Echinococcosis/hydatidosis: antigens, immunological and molecular diagnosis. Wallingford, Oxon, UK: CAB International,

Lightowlers, M. W., Liu, D. Y., Haralambous, A. \&Rickard, M. D. (1989). Subunit composition and specificity of the major cyst fluid antigens of Echinococcus granulosus. Mol Biochem Parasitol, Vol.37, No.2, pp. 171-182, ISSN: 0166-6851

Lightowlers, M. W., Rickard, M. D., Honey, R. D., Obendorf, D. L. \&Mitchell, G. F. (1984). Serological diagnosis of Echinococcus granulosus infection in sheep using cyst fluid antigen processed by antibody affinity chromatography. Aust Vet J, Vol.61, No.4, pp. 101-108,

Liu, D., Rickard, M. D. \&Lightowlers, M. W. (1993). Assessment of monoclonal antibodies to Echinococcus granulosus antigen 5 and antigen B for detection of human hydatid circulating antigens. Parasitology, Vol. 106, (Pt 1), pp. 75-81, ISSN: 0031-1820

Lorenzo, C., Ferreira, H. B., Monteiro, K. M., Rosenzvit, M., Kamenetzky, L., Garcia, H. H., Vasquez, Y., Naquira, C., Sanchez, E., Lorca, M., Contreras, M., Last, J. A. \&Gonzalez-Sapienza, G. G. (2005a). Comparative analysis of the diagnostic performance of six major Echinococcus granulosus antigens assessed in a doubleblind, randomized multicenter study. J Clin Microbiol, Vol.43, No.6, pp. 2764-2770, ISSN: 1098-660X

Lorenzo, C., Last, J. A. \&Gonzalez-Sapienza, G. G. (2005b). The immunogenicity of Echinococcus granulosus antigen 5 is determined by its post-translational modifications. Parasitology, Vol.131, (Pt 5), pp. 669-677, ISSN: 0031-1820

Lv, G. D., Liu, T., Lin, R. Y., Wang, X., Wang, J. H., Ren, Z. H., Wen, H. \&Lu, X. M. (2009). Immunoreactivity of the recombinant protein of Echinococcus granulosus antigen B. Zhongguo Ji Sheng Chong Xue Yu Ji Sheng Chong Bing Za Zhi, Vol.27, No.2, pp. 107110, ISSN: 1000-7423

Macpherson, C. N., Kachani, M., Lyagoubi, M., Berrada, M., Shepherd, M., Fields, P. F. \&El Hasnaoui, M. (2004). Cystic echinococcosis in the Berber of the Mid Atlas mountains, Morocco: new insights into the natural history of the disease in humans. Ann Trop Med Parasitol, Vol.98, No.5, pp. 481-490, ISSN: 1364-8594

Magambo, J. K., Zeyhle, Wachira, T. M., Wachira, J. \&Raasen, T. (1995). Cellular immunity to Echinococcus granulosus cysts. Afr J Health Sci, Vol.2, No.1, pp. 250-253, ISSN: 1478-2642

Mahmoud, M. S. \&Abou Gamra, M. M. (2004). Alkaline phosphatase from Echinococcus granulosus metacestodes for immunodiagnosis of human cystic echinococcosis. J Egypt Soc Parasitol, Vol.34, No.3, pp. 865-879, ISSN: 0253-5890

Mamuti, W., Sako, Y., Bart, J. M., Nakao, M., Ma, X., Wen, H. \&Ito, A. (2007). Molecular characterization of a novel gene encoding an 8-kDa-subunit of antigen B from Echinococcus granulosus genotypes 1 and 6. Parasitol Int., Vol.56, No.4, pp. 313-316, ISSN: 1383-5769

Manfras, B. J., Reuter, S., Wendland, T. \&Kern, P. (2002). Increased activation and oligoclonality of peripheral CD8(+) T cells in the chronic human helminth infection alveolar echinococcosis. Infect Immun, Vol.70, No.3, pp. 1168-1174, ISSN: 0019-9567

Margos, M. C., Grandgirard, D., Leib, S. \&Gottstein, B. (2011). In vitro induction of lymph node cell proliferation by mouse bone marrow dendritic cells following stimulation 
with different Echinococcus multilocularis antigens. J Helminthol, Vol.85, No.02, pp. 128-137, ISSN: 1475-2697

Marinova, I., Nikolov, G., Michova, A., Kurdova, R. \&Petrunov, B. (2011). Quantitative assessment of serum-specific IgE in the diagnosis of human cystic echinococcosis. Parasite Immunol, Vol.33, No.7, pp. 371-376, ISSN: 1365-3024

Matossian, R. M., Awar, G. N., Radwan, H., Craig, P. S. \&Meshefedjian, G. A. (1992). Immune status during albendazole therapy for hydatidosis. Ann Trop Med Parasitol, Vol.86, No.1, pp. 67-75, ISSN: 1364-8594

Matsumoto, J., Kouguchi, H., Oku, Y. \&Yagi, K. (2010). Primary alveolar echinococcosis: course of larval development and antibody responses in intermediate host rodents with different genetic backgrounds after oral infection with eggs of Echinococcus multilocularis. Parasitol Int, Vol.59, No.3, pp. 435-444, ISSN: 1383-5769

Matsumoto, J., Yagi, K., Nonaka, N., Oku, Y. \&Kamiya, M. (1998). Time-course of antibody response in mice against oral infection with eggs of Echinococcus multilocularis. Parasitology, Vol.116, (Pt 5), pp. 463-469, ISSN: 0031-1820

McManus, D. P. (2006). Molecular discrimination of taeniid cestodes. Parasitol Int 55 Suppl: S31-37, ISSN: 1383-5769

McManus, D. P. \&Thompson, R. C. (2003). Molecular epidemiology of cystic echinococcosis. Parasitology, Vol.127 Suppl: S37-51, ISSN: 0031-1820

McManus, D. P., Zhang, W., Li, J. \&Bartley, P. B. (2003). Echinococcosis. Lancet, Vol.362, No.9392, pp. 1295-1304,

McVie, A., Ersfeld, K., Rogan, M. T. \&Craig, P. S. (1997). Expression and immunological characterisation of Echinococcus granulosus recombinant antigen B for IgG4 subclass detection in human cystic echinococcosis. Acta Trop, Vol.67, No.1-2, pp. 19-35, ISSN: 0001-706X

Mejri, N., Muller, J. \&Gottstein, B. (2011a). Intraperitoneal murine Echinococcus multilocularis infection induces differentiation of TGF-beta expressing DCs that remain immature. Parasite Immunol, Vol.33, No.9, pp. 471-482, ISSN: 1365-3024

Mejri, N., Muller, N., Hemphill, A. \&Gottstein, B. (2011b). Intraperitoneal Echinococcus multilocularis infection in mice modulates peritoneal CD4+ and CD8+ regulatory $\mathrm{T}$ cell development. Parasitol Int, Vol.60, No.1, pp. 45-53, ISSN: 1383-5769

Mezioug, D. \&Touil-Boukoffa, C. (2009). Cytokine profile in human hydatidosis: possible role in the immunosurveillance of patients infected with Echinococcus granulosus. Parasite, Vol.16, No.1, pp. 57-64, ISSN 1252-607X

Moore, K. W., de Waal Malefyt, R., Coffman, R. L. \&O'Garra, A. (2001). Interleukin-10 and the interleukin-10 receptor. Annu Rev Immunol, Vol.19, pp. 683-765, ISSN: 0732-0582

Moosa, R. A. \&Abdel-Hafez, S. K. (1994). Serodiagnosis and seroepidemiology of human unilocular hydatidosis in Jordan. Parasitol Res, Vol.80, No.8, pp. 664-671, ISSN:09320113

Moro, P. L., Garcia, H. H., Gonzales, A. E., Bonilla, J. J., Verastegui, M. \&Gilman, R. H. (2005). Screening for cystic echinococcosis in an endemic region of Peru using portable ultrasonography and the enzyme-linked immunoelectrotransfer blot (EITB) assay. Parasitol Res, Vol.96, No.4, pp. 242-246, ISSN:0932-0113

Moro, P. L., McDonald, J., Gilman, R. H., Silva, B., Verastegui, M., Malqui, V., Lescano, G., Falcon, N., Montes, G. \&Bazalar, H. (1997). Epidemiology of Echinococcus granulosus 
infection in the central Peruvian Andes. Bull World Health Organ, Vol.75, No.6, pp. 553-561, ISSN:0042-9686

Muller, N., Frei, E., Nunez, S. \&Gottstein, B. (2007). Improved serodiagnosis of alveolar echinococcosis of humans using an in vitro-produced Echinococcus multilocularis antigen. Parasitology, Vol.134, (Pt 6), pp. 879-888, ISSN: 0031-1820

Myjak, P., Nahorski, W., Pietkiewicz, H., von Nickisch-Rosenegk, M., Stolarczyk, J., Kacprzak, E., Felczak-Korzybska, I., Szostakowska, B. \&Lucius, R. (2003). Molecular confirmation of human alveolar echinococcosis in Poland. Clin Infect Dis Vol. 37, No. 8, e121-125, ISSN:1537-6591

Nasrieh, M. A. \&Abdel-Hafez, S. K. (2004). Echinococcus granulosus in Jordan: assessment of various antigenic preparations for use in the serodiagnosis of surgically confirmed cases using enzyme immuno assays and the indirect haemagglutination test. Diagn Microbiol Infect Dis, Vol.48, No.2, pp. 117-123, ISSN: 0732-8893

Onyango-Abuje, J. A., Nginyi, J. M., Rugutt, M. K., Wright, S. H., Lumumba, P., Hughes, G. \&Harrison, L. J. (1996). Seroepidemiological survey of Taenia saginata cysticercosis in Kenya. Vet Parasitol, Vol.64, No.3, pp. 177-185, ISSN: 0304-4017

Ortona, E., Margutti, P., Delunardo, F., Nobili, V., Profumo, E., Rigano, R., Buttari, B., Carulli, G., Azzara, A., Teggi, A., Bruschi, F. \&Siracusano, A. (2005). Screening of an Echinococcus granulosus cDNA library with IgG4 from patients with cystic echinococcosis identifies a new tegumental protein involved in the immune escape. Clin Exp Immunol, Vol.142, No.3, pp. 528-538, ISSN: 1474-1741

Ortona, E., Rigano, R., Margutti, P., Notargiacomo, S., Ioppolo, S., Vaccari, S., Barca, S., Buttari, B., Profumo, E., Teggi, A. \&Siracusano, A. (2000). Native and recombinant antigens in the immunodiagnosis of human cystic echinococcosis. Parasite Immunol, Vol.22, No.11, pp. 553-559, ISSN: 1365-3024

Pawlowski, Z. S., Eckert, J., Vuitton, D. A., Ammann, R. W., Kern, P., Craig, P. S., Dar, F. K., De Rosa, F., Filice, C., Gottstein, B., Grimm, F., Macpherson, C. N. L., Sato, N., Todorov, T., Uchino, J., von Sinner, W. \&Wen, H. (2001). Echinococcosis in humans: clinical aspects, diagnosis and treatment, In: WHO/OIE Manual on Echinococcosis in Humans and Animals: a Public Health Problem of Global Concern, J. Eckert, M. A. Gemmell, F.-X. Mesli and Z. S. Pawlowski (Eds.) World Organisation for Animal Health and World Health Organisation, ISBN 92-9044-522-X, Paris, France.

Pearce, E. J. \&MacDonald, A. S. (2002). The immunobiology of schistosomiasis. Nat Rev Immunol, Vol.2, No.7, pp. 499-511, ISSN: 1474-1733

Peng, X., Li, J., Wu, X., Zhang, S., Niu, J., Chen, X., Yao, J. \&Sun, H. (2006). Detection of Osteopontin in the pericyst of human hepatic Echinococcus granulosus. Acta Trop, Vol.100, No.3, pp. 163-171, ISSN: 0001-706X

Petrova, R. F. (1968). Blood picture in experimental hydatidosis in sheep, Materiali Seminara-Soveshch. Borbe Gel'mint. Zhivot. Chimk. Alma-Ala, pp. 115-116 (in Russian).

Pinon, J. M., Poirriez, J., Lepan, H., Geers, R., Penna, R. \&Fernandez, D. (1987). Value of isotypic characterization of antibodies to Echinococcus granulosus by enzyme-linked immuno-filtration assay. Eur J Clin Microbiol, Vol.6, No.3, pp. 291-295, ISSN: 09349723

Poretti, D., Felleisen, E., Grimm, F., Pfister, M., Teuscher, F., Zuercher, C., Reichen, J. \&Gottstein, B. (1999). Differential immunodiagnosis between cystic hydatid disease 
and other cross-reactive pathologies. Am J Trop Med Hyg, Vol.60, No.2, pp. 193-198, ISSN: 0002-9637

Ravinder, P. T., Parija, S. C. \&Rao, K. S. (1997). Evaluation of human hydatid disease before and after surgery and chemotherapy by demonstration of hydatid antigens and antibodies in serum. J Med Microbiol, Vol.46, No.10, pp. 859-864, ISSN: 0022-2615

Ravinder, P. T., Parija, S. C. \&Rao, K. S. (2000). Urinary hydatid antigen detection by coagglutination, a cost-effective and rapid test for diagnosis of cystic echinococcosis in a rural or field setting. J Clin Microbiol, Vol.38, No.8, pp. 2972-2974, ISSN: 1098$660 X$

Read, A. J., Casey, J. L., Coley, A. M., Foley, M., Gauci, C. G., Jackson, D. C. \&Lightowlers, M. W. (2009). Isolation of antibodies specific to a single conformation-dependant antigenic determinant on the EG95 hydatid vaccine. Vaccine, Vol.27, No.7, pp. 10241031, ISSN: 0264-410X

Reiter-Owona, I., Gruner, B., Frosch, M., Hoerauf, A., Kern, P. \&Tappe, D. (2009). Serological confirmatory testing of alveolar and cystic echinococcosis in clinical practice: results of a comparative study with commercialized and in-house assays. Clin Lab, Vol.55, No.1-2, pp. 41-48, ISSN: 1433-6510

Rickard, M. D. (1984). Serological diagnosis and post-operative surveillance of human hydatid disease. I. Latex agglutination and immunoelectrophoresis using crude cyst fluid antigen. Pathology, Vol.16, No.2, pp. 207-210, ISSN: 0172-8113

Rickard, M. D., Honey, R. D., Brumley, J. L. \&Mitchell, G. F. (1984). Serological diagnosis and post-operative surveillance of human hydatid disease. II. The enzyme-linked immunosorbent assay (ELISA) using various antigens. Pathology, Vol.16, No.2, pp. 211-215, ISSN: 0172-8113

Rigano, R., Buttari, B., De Falco, E., Profumo, E., Ortona, E., Margutti, P., Scotta, C., Teggi, A. \&Siracusano, A. (2004). Echinococcus granulosus-specific T-cell lines derived from patients at various clinical stages of cystic echinococcosis. Parasite Immunol, Vol.26, No.1, pp. 45-52, ISSN: 1365-3024

Rigano, R., Buttari, B., Profumo, E., Ortona, E., Delunardo, F., Margutti, P., Mattei, V., Teggi, A., Sorice, M. \&Siracusano, A. (2007). Echinococcus granulosus antigen B impairs human dendritic cell differentiation and polarizes immature dendritic cell maturation towards a Th2 cell response. Infect Immun, Vol.75, No.4, pp. 1667-1678, ISSN: 0019-9567

Rigano, R., Profumo, E., Bruschi, F., Carulli, G., Azzara, A., Ioppolo, S., Buttari, B., Ortona, E., Margutti, P., Teggi, A. \&Siracusano, A. (2001). Modulation of human immune response by Echinococcus granulosus antigen $\mathrm{B}$ and its possible role in evading host defenses. Infect Immun, Vol.69, No.1, pp. 288-296, ISSN: 0019-9567

Rigano, R., Profumo, E., Buttari, B., Teggi, A. \&Siracusano, A. (1999a). Cytokine gene expression in peripheral blood mononuclear cells (PBMC) from patients with pharmacologically treated cystic echinococcosis. Clin Exp Immunol, Vol.118, No.1, pp. 95-101, ISSN: 1474-1741

Rigano, R., Profumo, E., Di Felice, G., Ortona, E., Teggi, A. \&Siracusano, A. (1995a). In vitro production of cytokines by peripheral blood mononuclear cells from hydatid patients. Clin Exp Immunol, Vol.99, No.3, pp. 433-439, ISSN: 1474-1741

Rigano, R., Profumo, E., Ioppolo, S., Notargiacomo, S., Ortona, E., Teggi, A. \&Siracusano, A. (1995b). Immunological markers indicating the effectiveness of pharmacological 
treatment in human hydatid disease. Clin Exp Immunol, Vol.102, No.2, pp. 281-285, ISSN: 1474-1741

Rigano, R., Profumo, E., Ioppolo, S., Notargiacomo, S., Teggi, A. \&Siracusano, A. (1999b). Serum cytokine detection in the clinical follow up of patients with cystic echinococcosis. Clin Exp Immunol, Vol.115, No.3, pp. 503-507, ISSN: 1474-1741

Rigano, R., Profumo, E., Teggi, A. \&Siracusano, A. (1996). Production of IL-5 and IL-6 by peripheral blood mononuclear cells (PBMC) from patients with Echinococcus granulosus infection. Clin Exp Immunol, Vol. 105, No.3, pp. 456-459, ISSN: 1474-1741

Ris, D. R., Hamel, K. L. \&Mackle, Z. M. (1987). Use of two polysaccharide antigens in ELISA for the detection of antibodies to Echinococcus granulosus in sheep sera. Res Vet Sci, Vol.43, No.2, pp. 257-263, ISSN: 0034-5288

Romig, T. (2009). Echinococcus multilocularis in Europe--state of the art. Vet Res Commun Vol.33 No. Suppl 1: 31-34, ISSN:1573-7446

Rosenzvit, M. C., Camicia, F., Kamenetzky, L., Muzulin, P. M. \&Gutierrez, A. M. (2006). Identification and intra-specific variability analysis of secreted and membranebound proteins from Echinococcus granulosus. Parasitol Int, Vol.55, Suppl: S63-67, ISSN: 1383-5769

Rott, M. B., Fernandez, V., Farias, S., Ceni, J., Ferreira, H. B., Haag, K. L. \&Zaha, A. (2000). Comparative analysis of two different subunits of antigen B from Echinococcus granulosus: gene sequences, expression in Escherichia coli and serological evaluation. Acta Trop, Vol.75, No.3, pp. 331-340, ISSN: 0001-706X

Sadjjadi, S. M., Abidi, H., Sarkari, B., Izadpanah, A. \&Kazemian, S. (2007). Evaluation of enzyme linked immunosorbent assay, utilizing native antigen $\mathrm{B}$ for serodiagnosis of human hydatidosis. Iran J Immunol, Vol.4, No.3, pp. 162-172, ISSN: 1735-1383

Sano, T., Smith, C. L. \&Cantor, C. R. (1992). Immuno-PCR: very sensitive antigen detection by means of specific antibody-DNA conjugates. Science, Vol.258, No.5079, pp. 120122, ISSN: 0036-8075

Schantz, P. M. (1988). Circulating antigen and antibody in hydatid disease. N Engl J Med, Vol.318, No.22, pp. 1469-1470, ISSN: 0028-4793

Shambesh, M. K., Craig, P. S., Wen, H., Rogan, M. T. \&Paolillo, E. (1997). IgG1 and IgG4 serum antibody responses in asymptomatic and clinically expressed cystic echinococcosis patients. Acta Trop, Vol.64, No.1-2, pp. 53-63, ISSN: 0001-706X

Shepherd, J. C., Aitken, A. \&McManus, D. P. (1991). A protein secreted in vivo by Echinococcus granulosus inhibits elastase activity and neutrophil chemotaxis. Mol Biochem Parasitol, Vol.44, No.1, pp. 81-90, ISSN: 0166-6851

Shepherd, J. C. \&McManus, D. P. (1987). Specific and cross-reactive antigens of Echinococcus granulosus hydatid cyst fluid. Mol Biochem Parasitol, Vol.25, No.2, pp. 143-154, ISSN: 0166-6851

Siles-Lucas, M. M. \&Gottstein, B. B. (2001). Molecular tools for the diagnosis of cystic and alveolar echinococcosis. Trop Med Int Health, Vol.6, No.6, pp. 463-475, ISSN: 13653156

Simsek, S. \&Koroglu, E. (2004). Evaluation of enzyme-linked immunosorbent assay (ELISA) and enzyme-linked immunoelectrotransfer blot (EITB) for immunodiagnosis of hydatid diseases in sheep. Acta Trop, Vol.92, No.1, pp. 17-24, ISSN: 0001-706X 
Siracusano, A., Buttari, B., Delunardo, F., Profumo, E., Margutti, P., Ortona, E., Rigano, R. \&Teggi, A. (2004). Critical points in the immunodiagnosis of cystic echinococcosis in humans. Parassitologia, Vol.46, No.4, pp. 401-403, ISSN: 0048-2951

Sjolander, A., Guisantes, J. A., Torres-Rodriguez, J. M. \&Schroder, H. (1989). The diagnosis of human hydatidosis by measurement of specific IgE antibody by enzyme immunoassay. Scand J Infect Dis, Vol.21, No.2, pp. 213-218, ISSN: 0036-5548

Speiser, F. (1980). Application of the enzyme-linked immunosorbent assay (ELISA) for the diagnosis of filariasis and echinococcosis. Tropenmed Parasitol, Vol.31, No.4, pp. 459466, ISSN: 0303-4208

Sterla, S., Sato, H. \&Nieto, A. (1999). Echinococcus granulosus human infection stimulates low avidity anticarbohydrate IgG2 and high avidity antipeptide IgG4 antibodies. Parasite Immunol, Vol.21, No.1, pp. 27-34, ISSN: 1365-3024

Tappe, D., Sako, Y., Itoh, S., Frosch, M., Gruner, B., Kern, P. \&Ito, A. (2010). Immunoglobulin $\mathrm{G}$ subclass responses to recombinant Em18 in the follow-up of patients with alveolar echinococcosis in different clinical stages. Clin Vaccine Immunol, Vol.17, No.6, pp. 944-948, ISSN: 1556-679X

Tawfeek, G. M., Elwakil, H. S., El-Hoseiny, L., Thabet, H. S., Sarhan, R. M., Awad, N. S. \&Anwar, W. A. (2011). Comparative analysis of the diagnostic performance of crude sheep hydatid cyst fluid, purified antigen B and its subunit (12 Kda), assessed by ELISA, in the diagnosis of human cystic echinococcosis. Parasitol Res, Vol.108, No.2, pp. 371-376, ISSN:0932-0113

Thompson, C. R. A. \&McManus, D. P. (2001). Aetiology: parasites and life-cycles. In: WHO/OIE Manual on Echinococcosis in Humans and Animals: a Public Health Problem of Global Concern, J. Eckert, M. A. Gemmell, F.-X. Mesli and Z. S. Pawlowski (Eds.) World Organisation for Animal Health and World Health Organisation, ISBN 929044-522-X, Paris, France

Vacirca, D., Perdicchio, M., Campisi, E., Delunardo, F., Ortona, E., Margutti, P., Teggi, A., Gottstein, B. \&Siracusano, A. (2011). Favourable prognostic value of antibodies anti-HSP20 in patients with cystic echinococcosis: a differential immunoproteomic approach. Parasite Immunol, Vol.33, No.3, pp. 193-198, ISSN: 1365-3024

van Doorn, H. R., Koelewijn, R., Hofwegen, H., Gilis, H., Wetsteyn, J. C., Wismans, P. J., Sarfati, C., Vervoort, T. \&van Gool, T. (2007). Use of enzyme-linked immunosorbent assay and dipstick assay for detection of Strongyloides stercoralis infection in humans. J Clin Microbiol, Vol.45, No.2, pp. 438-442, ISSN: 1098-660X

Varela-Diaz, V. M., Coltorti, E. A., Prezioso, U., Lopez-Lemes, M. H., Guisantes, J. A. \&Yarzabal, L. A. (1975a). Evaluation of three immunodiagnostic tests for human hydatid disease. Am J Trop Med Hyg, Vol.24, No.2, pp. 312-319, ISSN: 0002-9637

Varela-Diaz, V. M., Guisantes, J. A., Ricardes, M. I., Yarzabal, L. A. \&Coltorti, E. A. (1975b). Evaluation of whole and purified hydatid fluid antigens in the diagnosis of human hydatidosis by the immunoelectrophoresis test. Am J Trop Med Hyg, Vol.24, No.2, pp. 298-303, ISSN: 0002-9637

Varela-Diaz, V. M., Lopez-Lemes, M. H., Prezioso, U., Coltorti, E. A. \&Yarzabal, L. A. (1975c). Evaluation of four variants of the indirect hemagglutination test for human hydatidosis. Am J Trop Med Hyg, Vol.24, No.2, pp. 304-311, ISSN: 0002-9637 
Verastegui, M., Moro, P., Guevara, A., Rodriguez, T., Miranda, E. \&Gilman, R. H. (1992). Enzyme-linked immunoelectrotransfer blot test for diagnosis of human hydatid disease. J Clin Microbiol, Vol30, No.6, pp. 1557-1561, ISSN: 1098-660X

Virginio, V. G., Hernandez, A., Rott, M. B., Monteiro, K. M., Zandonai, A. F., Nieto, A., Zaha, A. \&Ferreira, H. B. (2003). A set of recombinant antigens from Echinococcus granulosus with potential for use in the immunodiagnosis of human cystic hydatid disease. Clin Exp Immunol, Vol.132, No.2, pp. 309-315, ISSN: 1474-1741

Virginio, V. G., Taroco, L., Ramos, A. L., Ferreira, A. M., Zaha, A., Ferreira, H. B. \&Hernandez, A. (2007). Effects of protoscoleces and AgB from Echinococcus granulosus on human neutrophils: possible implications on the parasite's immune evasion mechanisms. Parasitol Res, Vol.100, No.5, pp. 935-942, ISSN:0932-0113

Vogel, M., Gottstein, B., Muller, N. \&Seebeck, T. (1988). Production of a recombinant antigen of Echinococcus multilocularis with high immunodiagnostic sensitivity and specificity. Mol Biochem Parasitol, Vol.31, No.2, pp. 117-125, ISSN: 0166-6851

Vuitton, D. A. (2003). The ambiguous role of immunity in echinococcosis: protection of the host or of the parasite? Acta Trop, Vol.85, No.2, pp. 119-132, ISSN: 0001-706X

Vuitton, D. A. (2004). Echinococcosis and allergy. Clin Rev Allergy Immunol, Vol.26, No.2, pp. 93-104, ISSN:1080-0549

Vuitton, D. A., Bresson-Hadni, S., Laroche, L., Kaiserlian, D., Guerret-Stocker, S., Bresson, J. L. \&Gillet, M. (1989). Cellular immune response in Echinococcus multilocularis infection in humans. II. Natural killer cell activity and cell subpopulations in the blood and in the periparasitic granuloma of patients with alveolar echinococcosis. Clin Exp Immunol, Vol.78, No.1, pp.67-74, ISSN: 1474-1741

Wang, Y., He, T., Wen, X., Li, T., Waili, A., Zhang, W., Xu, X., Vuitton, D. A., Rogan, M. T., Wen, H. \&Craig, P. S. (2006). Post-survey follow-up for human cystic echinococcosis in northwest China. Acta Trop, Vol.98, No.1, pp. 43-51, ISSN: 0001$706 \mathrm{X}$

Wattal, C., Mohan, C. \&Agarwal, S. C. (1988). Evaluation of specific immunoglobulin E by enzyme-linked immunosorbent assay in hydatid disease. Int Arch Allergy Appl Immunol, Vol.87, No.1, pp. 98-100, ISSN: 1018-2438

Wen, H. \&Craig, P. S. (1994). Immunoglobulin G subclass responses in human cystic and alveolar echinococcosis. Am J Trop Med Hyg, Vol.51, No.6, pp. 741-748, ISSN: 00029637

Xiao, N., Mamuti, W., Yamasaki, H., Sako, Y., Nakao, M., Nakaya, K., Gottstein, B., Schantz, P. M., Lightowlers, M. W., Craig, P. S. \&Ito, A. (2003). Evaluation of use of recombinant Em18 and affinity-purified Em18 for serological differentiation of alveolar echinococcosis from cystic echinococcosis and other parasitic infections. $J$ Clin Microbiol, Vol.41, No.7, pp. 3351-3353, ISSN: 1098-660X

Yang, Y. R., Craig, P. S., Vuitton, D. A., Williams, G. M., Sun, T., Liu, T. X., Boufana, B., Giraudoux, P., Teng, J., Li, Y., Huang, L., Zhang, W., Jones, M. K. \&McManus, D. P. (2008). Serological prevalence of echinococcosis and risk factors for infection among children in rural communities of southern Ningxia, China. Trop Med Int Health, Vol.13, No.8, pp.1086-1094, ISSN: 1365-3156

Yang, Y. R., Sun, T., Zhang, J. Z. \&McManus, D. P. (2006). Molecular confirmation of a case of multiorgan cystic echinococcosis. J Parasitol, Vol.92, No.1, pp. 206-208, ISSN: 0022-3395 
Yong, W. K., Heath, D. D. \&Van Knapen, F. (1984). Comparison of cestode antigens in an enzyme-linked immunosorbent assay for the diagnosis of Echinococcus granulosus, Taenia hydatigena and T ovis infections in sheep. Res Vet Sci, Vol.36, No.1, pp. 24-31, ISSN: 0034-5288

Zarzosa, M. P., Orduna Domingo, A., Gutierrez, P., Alonso, P., Cuervo, M., Prado, A., Bratos, M. A., Garcia-Yuste, M., Ramos, G. \&Rodriguez Torres, A. (1999). Evaluation of six serological tests in diagnosis and postoperative control of pulmonary hydatid disease patients. Diagn Microbiol Infect Dis, Vol.35, No.4, pp. 255-262, ISSN: 0732-8893

Zhang, S., Hue, S., Sene, D., Penfornis, A., Bresson-Hadni, S., Kantelip, B., Caillat-Zucman, S. \&Vuitton, D. A. (2008a). Expression of major histocompatibility complex class I chain-related molecule A, NKG2D, and transforming growth factor-beta in the liver of humans with alveolar echinococcosis: new actors in the tolerance to parasites? J Infect Dis, Vol.197, No.9, pp. 1341-1349, ISSN: 0022-1899

Zhang, W., Li, J., Jones, M. K., Zhang, Z., Zhao, L., Blair, D. \&McManus, D. P. (2010). The Echinococcus granulosus antigen $\mathrm{B}$ gene family comprises at least 10 unique genes in five subclasses which are differentially expressed. PLoS Negl Trop Dis, Vol.4, No.8, pp. e784, ISSN: 1935-2735

Zhang, W., Li, J. \&McManus, D. P. (2003a). Concepts in immunology and diagnosis of hydatid disease. Clin Microbiol Rev, Vol.16, No.1, pp. 18-36, ISSN: 1098-6618

Zhang, W. \&McManus, D. P. (2006). Recent advances in the immunology and diagnosis of echinococcosis. FEMS Immunol Med Microbiol, Vol.47, No.1, pp. 24-41, ISSN: 09288244

Zhang, W., Ross, A. G. \&McManus, D. P. (2008b). Mechanisms of immunity in hydatid disease: implications for vaccine development. J Immunol, Vol.181, No.10, pp. 66796685, ISSN: 1550-6606

Zhang, W., You, H., Li, J., Zhang, Z., Turson, G., Aili, H., Wang, J. \&McManus, D. P. (2003b). Immunoglobulin profiles in a murine intermediate host model of resistance for Echinococcus granulosus infection. Parasite Immunol, Vol.25, No.3, pp. 161-168, ISSN: 1365-3024

Zhang, W., You, H., Zhang, Z., Turson, G., Hasyet, A. \&McManus, D. P. (2001). Further studies on an intermediate host murine model showing that a primary Echinococcus granulosus infection is protective against subsequent oncospheral challenge. Parasitol Int, Vol.50, No.4, pp. 279-283, ISSN: 1383-5769

Zhang, W. B., Li, J., Li, Q., Yang, D., Zhu, B., You, H., Jones, M. K., Duke, M. \&McManus, D. P. (2007). Identification of a diagnostic antibody-binding region on the immunogenic protein EpC1 from Echinococcus granulosus and its application in population screening for cystic echinococcosis. Clin Exp Immunol, Vol.149, No.1, pp. 80-86, ISSN: 1474-1741

Zhang, W. B. \&Zhao, D. Z. (1992). A comparison of calcification of hydatid cysts in sheep pasturred and post-feeded. Chinese Journal of Veterinary Science $\mathcal{E}$ Technology, Vol.22, No.9, pp. 28-29 (in Chinese), ISSN: 1673-4696 


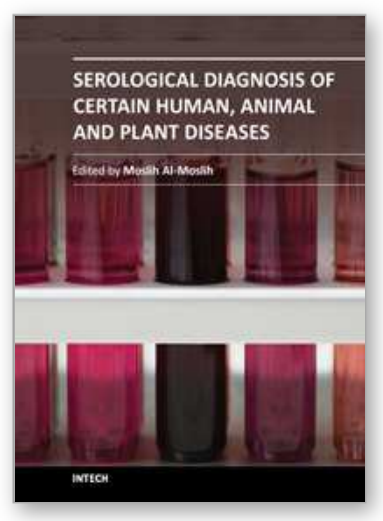

\section{Serological Diagnosis of Certain Human, Animal and Plant \\ Diseases}

Edited by Dr. Moslih Al-Moslih

ISBN 978-953-51-0370-7

Hard cover, 170 pages

Publisher InTech

Published online 21, March, 2012

Published in print edition March, 2012

This book explains the concept of serological methods used in laboratory diagnoses of certain bacteria, mycoplasmas, viruses in humans, animals and plants, certain parasitic agents as well as autoimmune disease. The authors present up-to-date information concerning the serological methods in laboratory diagnosis of such infectious diseases. Section one deals with the serological methods for bacteria. Section 2 deals with serological methods in human, animal and plant viruses. Section 3 is concerned with the serological laboratory diagnosis of echinococcus and human toxocariasis agents. The last section deals with serological laboratory methods in the diagnosis of coeliac disease.

\section{How to reference}

In order to correctly reference this scholarly work, feel free to copy and paste the following:

Wenbao Zhang, Jun Li, Renyong Lin, Hao Wen and Donald P. McManus (2012). Recent Advances in the Immunology and Serological Diagnosis of Echinococcosis, Serological Diagnosis of Certain Human, Animal and Plant Diseases, Dr. Moslih Al-Moslih (Ed.), ISBN: 978-953-51-0370-7, InTech, Available from:

http://www.intechopen.com/books/serological-diagnosis-of-certain-human-animal-and-plant-diseases/recentadvances-in-the-serological-diagnosis-of-echinococcosis

\section{INTECH}

open science | open minds

\section{InTech Europe}

University Campus STeP Ri

Slavka Krautzeka 83/A

51000 Rijeka, Croatia

Phone: +385 (51) 770447

Fax: +385 (51) 686166

www.intechopen.com

\section{InTech China}

Unit 405, Office Block, Hotel Equatorial Shanghai

No.65, Yan An Road (West), Shanghai, 200040, China

中国上海市延安西路65号上海国际贵都大饭店办公楼 405 单元

Phone: +86-21-62489820

Fax: $+86-21-62489821$ 
(C) 2012 The Author(s). Licensee IntechOpen. This is an open access article distributed under the terms of the Creative Commons Attribution 3.0 License, which permits unrestricted use, distribution, and reproduction in any medium, provided the original work is properly cited. 